\title{
The settlement performance of stone column foundations
}

\author{
J. A. BLACK* , V. SIVAKUMAR $\dagger$ and A. BELL
}

\begin{abstract}
Vibrated stone columns are frequently used as a method of reinforcing soft ground as they provide increased bearing capacity and reduce foundation settlements. Their performance in relation to bearing capacity is well documented, but there is also a need for enhanced understanding of their settlement characteristics, particularly in relation to small-group configurations. This paper presents results obtained from physical model tests on triaxial specimens $300 \mathrm{~mm}$ in diameter and $400 \mathrm{~mm}$ high. Parameters investigated include column length to diameter ratio, area replacement ratio and single/group configuration. The findings of the work are as follows. The design is flexible: settlement can equally be controlled using short columns at relatively high area replacement ratios, or longer columns at smaller area replacement ratios. An optimum area replacement ratio of $30-40 \%$ exists for the control of settlement. The settlement performance of a small column group is highly influenced by inter-column and footing interaction effects.
\end{abstract}

KEYWORDS: footings/foundations; ground improvement; model tests; reinforced soils; settlement; soil/structure interaction
On utilise fréquemment des colonnes en pierre vibrée pour le renforcement de sols tendres, car elles accroissent la capacité portante tout en réduisant le tassement des fondations. Bien que leur performances relativement à la capacité portante soit bien documentée, il est nécessaire de renforcer les connaissances sur leurs propriétés de tassement, notamment en présence de configurations de groupes restreints. La présente communication illustre les résultats obtenus à l'issue d'essais sur maquettes de $\mathbf{3 0 0}$ $\mathrm{mm}$ de diamètre $\times \mathbf{4 0 0} \mathrm{m}$ de haut. Parmi les paramètres examinés, on indiquera le ratio longueur /diamètre de la colonne, le ratio superficie - remplacement, et la configuration individuelle /en groupe. Les conclusions de ces travaux indiquent (i) une flexibilité conceptuelle, dans le cadre de laquelle il est possible de limiter le tassement aussi bien en utilisant des colonnes courtes avec des ratios superficie - remplacement relativement élevés qu'en utilisant des colonnes plus longues avec ratios superficie - remplacement inférieurs; (ii) la présence d'un ratio superficie - remplacement optimum compris entre 30 et $40 \%$ pour la limitation du tassement; et (iii) que les effets de l'interaction inter-colonnes et de la semelle influent fortement sur les caractéristiques de tassement de petits groupes de colonnes.

\section{INTRODUCTION}

The stone column technique has witnessed significant applications, due to its versatility in treating soft cohesive soils and mixed fills of variable geotechnical properties. Laboratory-based research, together with analytical modelling, numerical modelling and field observations, is well documented, and has contributed to improvements in efficiency and quality control (Hughes \& Withers, 1974; Hughes et al., 1975; Aboshi et al., 1979; Balaam \& Booker, 1981; Barksdale \& Bachus, 1983; Charles \& Watts, 1983; Alamgir et al., 1994; Hu, 1995; Balaam et al., 1977; Raju, 1997; Slocombe et al., 2000; Watts et al., 2000; Watts \& Serridge, 2000; McKelvey, 2002; McKelvey et al., 2004; Pulko \& Majes, 2005; Black, 2007; Black et al., 2007a, 2007b; McCabe et al., 2009). Stone columns are typically employed to support large raft foundations at relatively low or moderate loading conditions. However, more recently they have also been deployed beneath small isolated pad or strip foundations. Many previous studies have focused predominantly on the aspect of bearing capacity, although a small number of these projects have presented settlement data as a secondary aspect.

The effectiveness and performance of the stone column technique is influenced by several factors, including the

Manuscript received 11 February 2009; revised manuscript accepted 27 September 2010. Published online ahead of print 22 February 2011. Discussion on this paper closes on 1 April 2012, for further details see p. ii.

* Department of Civil and Structural Engineering, University of Sheffield, UK (formerly postgraduate student at Queen's University Belfast).

$\dagger$ School of Planning, Architecture and Civil Engineering, Queen's

University Belfast, UK.

$\$$ Keller Ground Engineering, Coventry, UK. column length to diameter ratio $(L / d)$, the area replacement ratio $\left(A_{\mathrm{S}}\right)$, the column spacing $(s)$, the stiffness of the column $\left(E_{\mathrm{c}}\right)$ and of the surrounding soil $\left(E_{\mathrm{s}}\right)$, the stress ratio of the column and soil $\left(\sigma_{\mathrm{vc}} / \sigma_{\mathrm{vs}}\right)$, the number of columns beneath the footing and the method of installation (Fig. 1). Hu (1995) studied extensively the behaviour and failure mechanisms of a large group of stone columns in relation to bearing capacity, and McKelvey (2002) investigated the performance of small-group behaviour beneath pad and strip footings. The latter work revealed that short columns $(L / d<6)$ failed in end bearing, whereas longer columns $(L / d>6)$ failed by bulging. These observations agreed with previous postulations by Wood et al. (2000) and Hughes \& Withers (1974).

Current design techniques for settlement control relate to large-group configurations, and are analysed based on the performance of an isolated column under unit cell conditions (Priebe, 1995). This approach delivers good correlation with actual observed field behaviour for infinite groups, but discrepancies exist when it is applied to small-group column configurations. This is attributed to complex group interaction effects, which make confident predictions of settlement performance problematic (McCabe et al., 2009). The work reported in this paper addresses the limitations associated with previous investigations, and uses reduced scale physical models to provide valuable insight into the settlement performance of isolated and small groups of stone columns.

\section{EQUIPMENT DEVELOPMENT, SAMPLING, COLUMN INSTALLATION AND TESTING PROGRAMME}

A review of previous investigations showed that soil beds were prepared and restrained in one-dimensional consolidation chambers during foundation loading. Two issues 

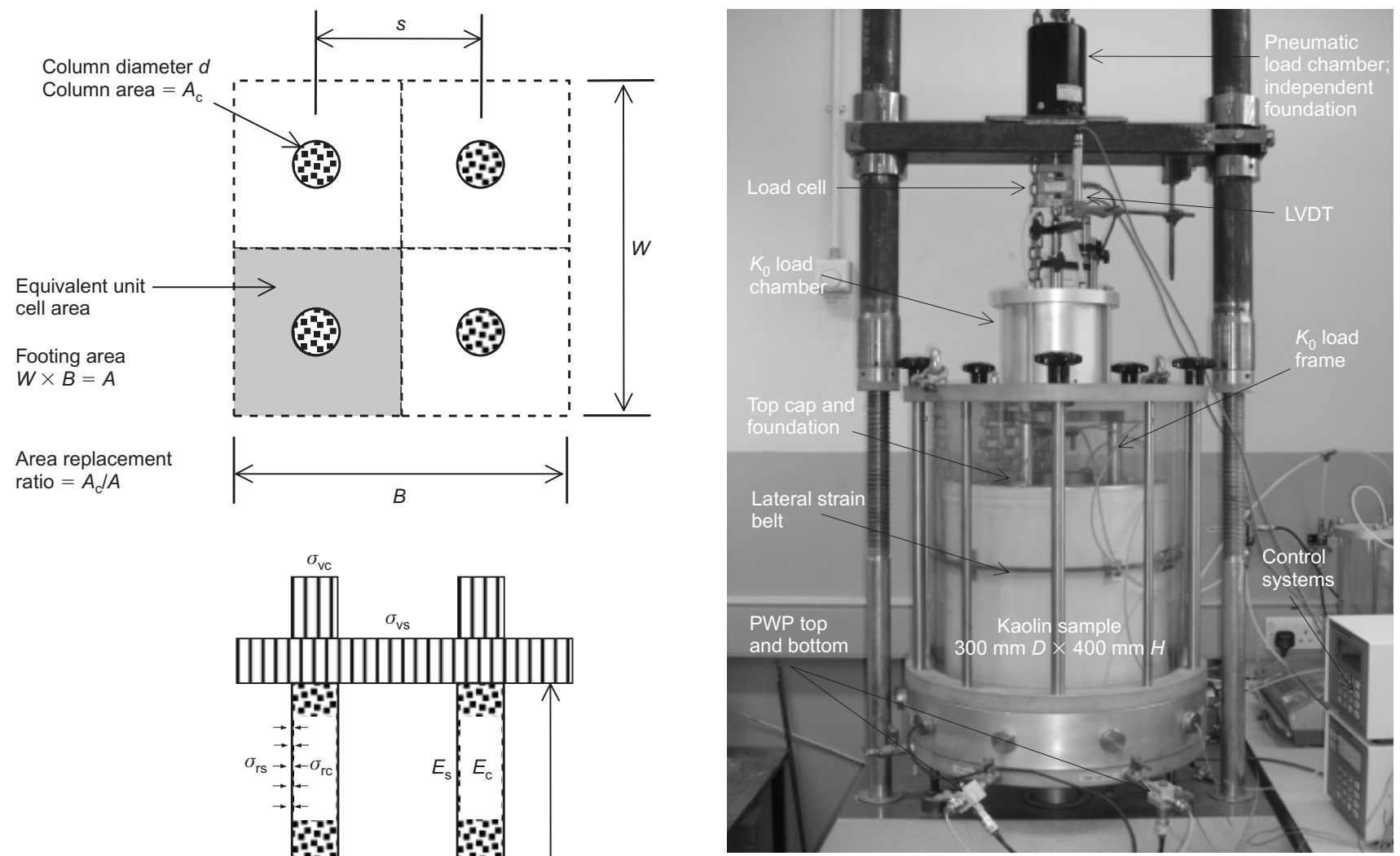

Fig. 2. Newly developed calibration triaxial cell apparatus and controlling system

activated by this unit applied additional stress to the sample top plate by way of an internal loading frame.

(b) Independent foundation loading was applied. Foundation loading was achieved using a small, independent $60 \mathrm{~mm}$ diameter footing located within the top plate (Fig. 3). A pneumatic piston located on the cross-beam of the support frame activated a ram that ran through the centre of the $K_{0}$ load chamber and load frame.

Fig. 1. Key factors affecting granular columns' performance

associated with this technique hinder the evaluation of settlement performance: (a) a lack of control of pore water pressure under foundation loading, and (b) frictional resistance, leading to non-uniform soil stiffness/strength properties. To mitigate these problems a novel protocol was adopted. Samples were initially prepared by one-dimensional consolidation, and then transferred to a large triaxial cell for re-consolidation under isotropic stress. This system allowed for the control of confining and pore water pressure, and offered the additional benefit of a non-rigid 'free' lateral boundary. The following sections describe the features of this large triaxial cell, and the associated sampling method and column installation process.

\section{Equipment development}

A large triaxial cell, capable of testing samples $300 \mathrm{~mm}$ in diameter by $400 \mathrm{~mm}$ high, was designed and constructed (Fig. 2). Several distinctive features were necessary to meet the specific criteria of the current investigation, as follows.

(a) Independent control of vertical and lateral pressures was provided for the purpose of achieving $K_{0}$ consolidation. Confining pressure $\left(\sigma_{3}\right)$ was applied via the cell fluid, and the vertical pressure $\left(\sigma_{1}\right)$ was independently controlled using a rolling diaphragm type loading system located externally at the top of the cell ( $K_{0}$ loading chamber) (Fig. 2). The force

The foundation was instrumented with two pressure cells (2000 $\mathrm{kPa}$ range) to monitor the contact pressure (Fig. 3), one located at the centre of the footing (PT1), and the other at a radius of $18 \mathrm{~mm}$ (PT2). A third pressure cell (PT3)

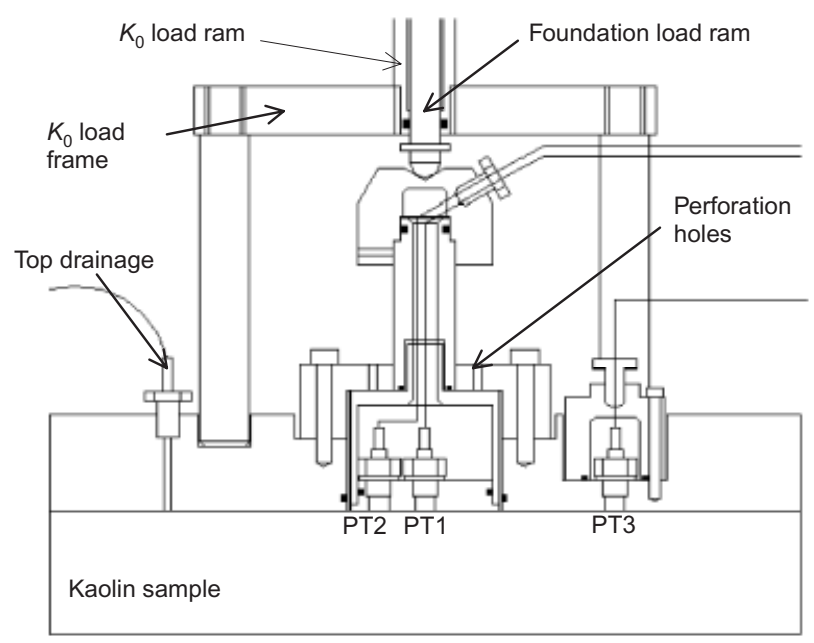

Fig. 3. Dual loading device: surcharge and independent foundation loading 
(1000 $\mathrm{kPa}$ range), located away from the foundation, measured the vertical stress in the surrounding soil.

Displacement of the independent foundation and top plate (surrounding clay) were measured using separate $50 \mathrm{~mm}$ and $20 \mathrm{~mm}$ stroke linear variable differential transformer (LVDT) devices respectively. Cell pressure, pore water pressure and the pneumatic load chamber to apply independent foundation loading were controlled using automatic pressure controllers. Radial displacement of the sample during $K_{0}$ and foundation loading was monitored using a submersible $10 \mathrm{~mm}$ LVDT mounted on a lateral strain calliper, based on the original configuration proposed by Menzies (1976). This was located $120 \mathrm{~mm}$ from the top of the sample. All instrumentation was interfaced with a 16channel data logger (MPX 3000) for data acquisition.

\section{Sampling}

The standard approach used by many researchers to make large samples is similar to a Rowe cell configuration (Rowe $\&$ Barden, 1966). This particular technique works satisfactorily in shorter consolidation chambers; however, difficulties have been reported, such as over-stretching of the bellows, and loss of consolidation pressure (Anderson et al., 1991; McKelvey, 2002; Navaneethan, 2003; Ahmadi \& Robertson, 2004). To mitigate this problem, a simple arrangement was adopted whereby the seal between the piston and the consolidation chamber was achieved using an inflatable O-ring (Fig. 4(a)).

The consolidation chamber (Fig. 4(b)) was fabricated from a polyethylene mains water pipe, machined to leave a bore of $300 \mathrm{~mm}$ and height of $900 \mathrm{~mm}$. The top and bottom plates of the chamber were manufactured from aluminium, and were fitted with porous filter discs and drainage facilities. A pressure cell was located in the base plate to monitor the earth pressure at the base of the chamber. The piston plate was manufactured from polyvinyl chloride (PVC), and was $298 \mathrm{~mm}$ in diameter by $60 \mathrm{~mm}$ thick. A bicycle tube (inflatable O-ring) was located in a groove, as shown in Fig. 4(a), and was connected to a regulated air line so that it could be inflated to achieve a seal between the piston and the chamber. Drainage was allowed from the base of the sample.

Samples were prepared by consolidating kaolin slurry,

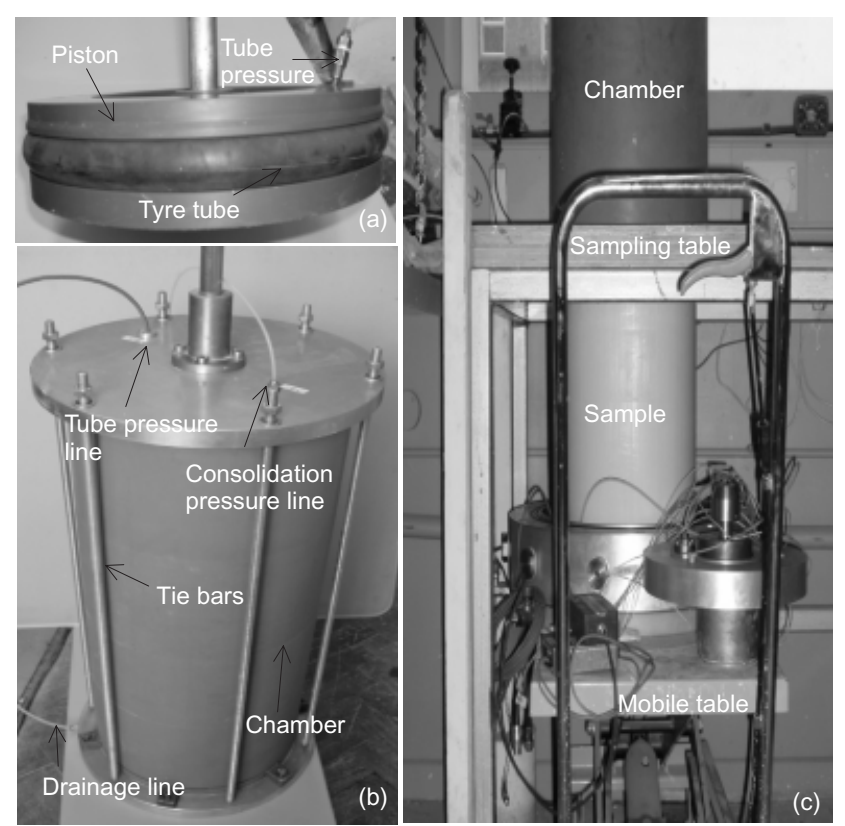

Fig. 4. (a) Innovative piston sealing arrangement; (b) consolidation chamber; (c) sample extrusion prepared at a water content of 1.5 times the liquid limit $(70 \%)$, to a vertical pressure of $150 \mathrm{kPa}$. This pressure was adequate to produce quality repeatable samples with undrained shear strength, $c_{\mathrm{u}}=35 \mathrm{kPa}$. Silicone grease was smeared on the inner cylindrical surface to reduce friction; this also aided sample extrusion after consolidation. Internal earth pressure measurements recorded at the base of the chamber during consolidation indicated that the pressure reduced from $157 \mathrm{kPa}(7 \mathrm{kPa}$ more than the applied pressure due to self-weight of the slurry) to $98 \mathrm{kPa}$ at the end of consolidation. This would imply that the clay at the bottom (from where the drainage was allowed) was slightly overconsolidated, as a result of unloading arising from frictional resistance. Further evidence to support this observation was determined from the void ratio of the spoil removed during column installation along the depth of the sample. As highlighted, variation of sample strength and stiffness with depth was present in previous experimental investigations; however, the effects of this in the current work are reduced, as the sample was reconsolidated under isotropic stress.

Consolidation of $95 \%$ was achieved in approximately 14 days, after which the consolidation and tube pressures were reduced with the drainage line closed. Using a specially fabricated sampling table, specimens were extruded from the consolidation chamber into position on the triaxial base, resting on a vertical mobile table (Fig. 4(c)), and trimmed to $400 \mathrm{~mm}$ high using a wire saw.

\section{Column installation}

Various methods of column installation, ranging from preforming frozen columns to forced intrusion and replacement/ compaction, were considered as part of this investigation (Black, 2007). Pre-forming resulted in reduced column density upon thawing. Forced intrusion was more representative of actual field installation, as it displaced the surrounding soil, generating densification (Egan et al., 2008), but the technique was difficult to implement in a small-scale model; furthermore, trial tests generated suction during removal of the poker which caused collapse of the cavity. Replacement was also trialled; although the technique is not entirely representative of field conditions, it proved to produce columns of excellent consistency, and has been adopted for the present research.

The holes were carefully bored using helical augers, which rotated at a constant speed of $19 \mathrm{rev} / \mathrm{min}$, with a vertical penetration of $25 \mathrm{~mm}$. Granular aggregate (crushed basalt) was then introduced to the cavity in stages, and compacted using a $1.0 \mathrm{~kg}$ metal rod free-falling through a fixed distance of $50 \mathrm{~mm}$ for a series of 10 blows. The aggregate was of uniform grading, with particle size in the range $1.18-2.36 \mathrm{~mm}$, and was in keeping with a $1: 30$ scale prototype. The average dry column density was calculated as $1648 \mathrm{~kg} / \mathrm{m}^{3} \pm 2 \%$, based on the assumption of constant cavity volume during installation. It is evident that some degree of cavity expansion will occur during compaction, and therefore this measurement was strictly used as a means of ensuring quality control between tests. Compaction of the same aggregate into a rigid container of a known volume showed that the dry density was approximately $1550 \mathrm{~kg} / \mathrm{m}^{3}$, implying that the installation of columns in the clay bed would have resulted in a $6 \%$ increase in cavity volume.

Each column was completed by infiltrating with de-aired water, and the placement of a thin layer of fine sand. This layer was vital to ensure that the pressure cells beneath the footing were subjected to a uniformly distributed load (UDL) rather than a point load from the crushed aggregate. Additional material characteristics for kaolin and basalt aggregate are provided in Table 1. 
Table 1. Material properties

\begin{tabular}{l|c|c}
\hline Material & Property & Value \\
\hline Clay: Speswhite kaolin clay & Particle size: $\mu \mathrm{m}$ & $<63$ \\
& Liquid limit: $\%$ & 68 \\
& Plastic limit: $\%$ & 34 \\
& Plasticity index: $\%$ & 34 \\
& Modulus of elasticity, $E^{\prime}: \mathrm{kN} / \mathrm{m}^{2}$ & 4 \\
& Friction angle, $\phi:$ degrees & 22 \\
Basalt aggregate: crushed basalt, uniformly & Undrained shear strength: $\mathrm{kN} / \mathrm{m}^{2}$ & 35 \\
graded & Compression index, $C_{\mathrm{c}}$ & $0 \cdot 47$ \\
& Swelling index, $C_{\mathrm{s}}$ & $0 \cdot 12$ \\
& Particle size: $\mathrm{mm}$ & $1 \cdot 18-2 \cdot 36$ \\
& Modulus of elasticity, $E^{\prime}: \mathrm{kN} / \mathrm{m}^{2}$ & 30 \\
& Friction angle, $\phi:$ degrees & 43 \\
\hline
\end{tabular}

\section{Testing programme}

The testing programme focused on assessing the effects of $A_{\mathrm{s}}, L / d$ and the number of columns beneath the footing (Table 2). The diameters for the column under isolated column conditions were $25 \mathrm{~mm}, 32 \mathrm{~mm}$ and $38 \mathrm{~mm}$, which correspond to area replacement ratios of $17 \%, 28 \%$ and $40 \%$ beneath the $60 \mathrm{~mm}$ footing respectively. For the group configuration, three columns of $18 \mathrm{~mm}$ and $22 \mathrm{~mm}$ diameter were adopted, as these provided $A_{\mathrm{s}}$ values correlating with the single column of $28 \%$ and $40 \%$. Three column lengths $125 \mathrm{~mm}, 250 \mathrm{~mm}$ and $400 \mathrm{~mm}$ - were considered, which represent $H_{\mathrm{c}} / H_{\mathrm{s}}$ ratios of $0.31,0.62$ and 1 respectively (where $H_{\mathrm{c}}$ and $H_{\mathrm{s}}$ are the lengths of the column and sample respectively). $H_{\mathrm{c}} / H_{\mathrm{s}}=1$ represents a fully penetrating column; $H_{\mathrm{c}} / H_{\mathrm{s}}<1$ represents a floating column. Initial saturation of the sample was conducted, to eliminate air voids trapped in the column during installation. This was followed by consolidation of the sample under a confining pressure of $275 \mathrm{kPa}$ and back-pressure of $200 \mathrm{kPa}$, which lasted for approximately 4 days, whereas for reinforced samples drainage accelerated to 2 days when a fully penetrating column was present.

Isotropic confinement was followed by $K_{0}$ consolidation, where the total vertical and horizontal stresses were increased to $341 \mathrm{kPa}$ and $300 \mathrm{kPa}$ from $275 \mathrm{kPa}$, representing a $K_{0}$ of 0.71 . This was conducted in order to produce more realistic field stress conditions, and allow for surcharge during independent footing load. In addition, under $K_{0}$ consolidation the configuration is representative of the unit cell concept, and enables further analysis under this consideration. The required stress path to achieve $K_{0}$ consolidation was determined using stress path apparatus on a small specimen, $50 \mathrm{~mm}$ in diameter and $100 \mathrm{~mm}$ high, which was extracted from the larger sample after the initial one-dimensional consolidation. This stress path was approximately linear, and was imposed on the $300 \mathrm{~mm}$ diameter sample in the large triaxial cell by ramping the horizontal and vertical stresses at the required rates. This procedure was adopted as the control software did not incorporate real-time feedback to execute complex stress path loading.

Figure 5 presents the lateral displacement response during $K_{0}$ loading for samples TS-01, TS-07 and TS-10. It is evident that the simplified approach to achieve $K_{0}$ proved successful for TS01 (unreinforced), as the imposed stress path resulted in virtually zero lateral strain; however, in reinforced tests the intended true $K_{0}$ stress path was not fully achieved, as slight lateral straining occurred (Fig. 5, TS-07 and TS-10; negative values represent contraction). This is attributed to variation in stiffness of the stone column and surrounding clay: therefore the applied stress path is referred to as the apparent $K_{0}$ path in the remainder of the paper. The implications of this apparent $K_{0}$ path and the consequence of lateral straining will be discussed later. In all column tests, the lateral strains experienced during the apparent $K_{0}$ loading were below $0 \cdot 1 \%$.

The third and final stage of testing involved applying

Table 2. Test schedule

\begin{tabular}{|c|c|c|c|c|c|c|}
\hline Test & $\begin{array}{c}\text { Column } \\
\text { configuration }\end{array}$ & $\begin{array}{c}\text { Column length, } \\
L: \mathrm{mm}\end{array}$ & $\begin{array}{c}\text { Column diameter, } \\
d: \mathrm{mm}\end{array}$ & $\begin{array}{l}\text { Area replacement } \\
\text { ratio, } A_{\mathrm{s}}: \%\end{array}$ & \multicolumn{2}{|c|}{$L / d$ ratio } \\
\hline TS-01 & Unreinforced & $\mathrm{N} / \mathrm{A}$ & $\mathrm{N} / \mathrm{A}$ & $\mathrm{N} / \mathrm{A}$ & \multicolumn{2}{|c|}{$\mathrm{N} / \mathrm{A}$} \\
\hline TS-02 & Isolated & 125 & 25 & 17 & \multicolumn{2}{|c|}{$5 \cdot 0$} \\
\hline TS-03 & Isolated & 250 & 25 & 17 & \multicolumn{2}{|c|}{$10 \cdot 0$} \\
\hline TS-04 & Isolated & 400 & 25 & 17 & \multicolumn{2}{|c|}{$16 \cdot 0$} \\
\hline TS-05 & Isolated & 125 & 32 & 28 & \multicolumn{2}{|c|}{$3 \cdot 9$} \\
\hline TS-06 & Isolated & 250 & 32 & 28 & \multicolumn{2}{|c|}{$7 \cdot 8$} \\
\hline TS-07 & Isolated & 400 & 32 & 28 & \multicolumn{2}{|c|}{$12 \cdot 5$} \\
\hline TS-08 & Isolated & 125 & 38 & 40 & \multicolumn{2}{|c|}{$3 \cdot 3$} \\
\hline TS-09 & Isolated & 250 & 38 & 40 & \multicolumn{2}{|c|}{$6 \cdot 6$} \\
\hline TS-10 & Isolated & 400 & 38 & 40 & \multicolumn{2}{|c|}{$10 \cdot 5$} \\
\hline TS-11 & Group & 250 & $18 \times 3$ & 40 & $13 \cdot 8$ & $4 \cdot 1^{*}$ \\
\hline TS-12 & Group & 400 & $18 \times 3$ & 28 & $22 \cdot 2$ & $6 \cdot 6^{*}$ \\
\hline TS-13 & Group & 250 & $22 \times 3$ & 28 & $11 \cdot 3$ & $4 \cdot 1^{*}$ \\
\hline TS-14 & Group & 400 & $22 \times 3$ & 40 & $18 \cdot 1$ & $6 \cdot 6^{*}$ \\
\hline
\end{tabular}

${ }^{*}$ Calculated using $L / d_{\mathrm{g}}$, where $d_{\mathrm{g}}=$ group diameter. 
Lateral displacement: $\mathrm{mm}$

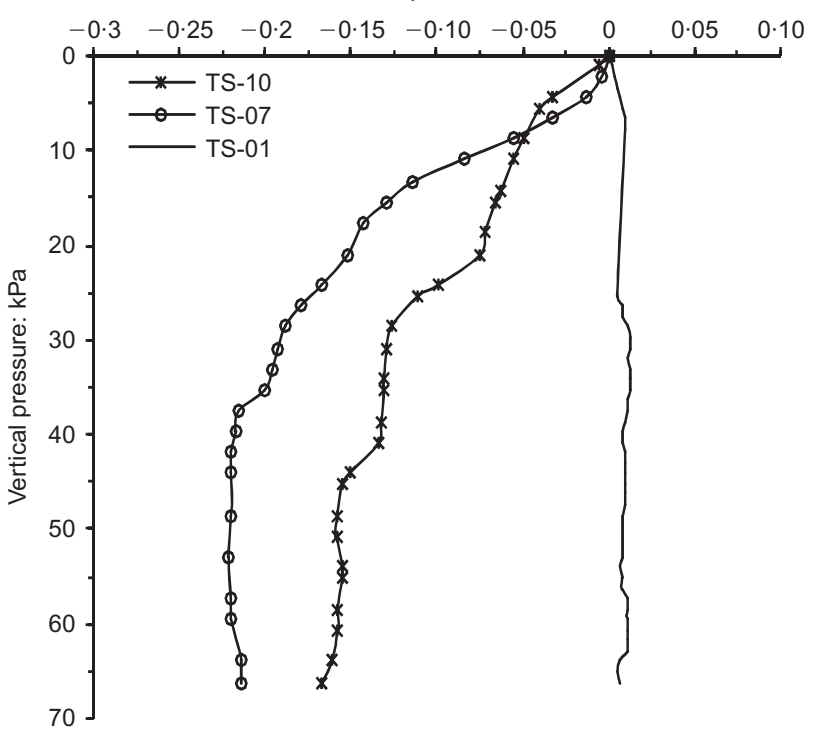

Fig. 5. Lateral displacement response during $K_{0}$ loading for a sample reinforced with fully penetrating columns $H_{\mathrm{c}} / H_{\mathrm{s}}=1$

independent foundation loading under drained conditions. To determine an appropriate loading rate, a trial test was performed on an unreinforced sample, in which foundation load was applied at a loading rate of $1 \mathrm{kPa} / \mathrm{h}$ while drainage through the top of the sample was not permitted; $2 \mathrm{kPa}$ of excess pore water pressure developed. In reinforced tests, drainage capacity was enhanced, due to the presence of a stone column, together with top drainage being permitted. Therefore the trial loading rate of $1 \mathrm{kPa} / \mathrm{h}$ was deemed sufficient to ensure fully drained conditions.

\section{RESULTS AND DISCUSSION}

Due to the complexity and extent of the investigation, it is not possible to present all the data generated as part of the study. Therefore the authors have chosen to provide information that emphasises the most significant findings from the research. The aspects examined in detail in the remainder of this paper are

(a) performance of samples during initial and $K_{0}$ consolidation

(b) performance of the foundation reinforced by a single column

(c) performance of the foundation reinforced by a group of three columns

(d) settlement control using stone columns.

\section{Performance of samples during initial and apparent $K_{0}$ consolidation}

The unit cell configuration assumes that an end bearing column and the surrounding clay are strained equally in the vertical direction, while zero lateral displacement is maintained at the outer boundary. On the basis of the above description, the apparent $K_{0}$ consolidation stage was considered as a close approximation to a unit cell, as the lateral strains were small. As the full sample cross-sectional area is loaded (by way of the $300 \mathrm{~mm}$ rigid top plate) during the apparent $K_{0}$ consolidation, the effective area replacement ratio is recalculated for the single column diameters of $25 \mathrm{~mm}$, $32 \mathrm{~mm}$ and $38 \mathrm{~mm}$ as $0.7 \%, 1.1 \%$ and $1.6 \%$ respectively. Note that during the foundation loading stage the column diameters above reflect area replacement ratios of $17 \%, 28 \%$ and $40 \%$ respectively beneath the isolated $60 \mathrm{~mm}$ diameter footing.

Figure 6 shows the vertical displacement plotted against the vertical stress for samples with fully penetrating columns of diameters $25 \mathrm{~mm}, 32 \mathrm{~mm}$ and $38 \mathrm{~mm}$, and the unreinforced sample. The axial strains experienced by the composite samples (TS-04, TS-07 and TS-10) were $0.77 \%, 0 \cdot 72 \%$ and $0.54 \%$ for area replacement ratios of $0.7 \%, 1.1 \%$ and $1.6 \%$ respectively, compared with $1.5 \%$ for the unreinforced sample. This yields settlement improvement factors $n$, defined as the ratio between untreated $\left(S_{\mathrm{ut}}\right)$ and treated $\left(S_{\mathrm{t}}\right)$ settlement, of $1 \cdot 9,2 \cdot 1$ and $2 \cdot 8$ respectively, which are greater than those determined by Priebe (1995) of 1.04, 1.06 and 1.10 respectively, based on Poisson's ratio of the soil, $v_{\mathrm{s}}^{\prime}=0.33$ and friction angle for granular material, $\phi_{\mathrm{c}}^{\prime}=45^{\circ}$ ). Apart from scale effects, a possible explanation for these differences could relate to the fact that Priebe (1995) does not account for foundation rigidity, and is based on flexible footing conditions.

Figures 7(a) and 7(b) show the pressure-displacement characteristics of samples installed with partially penetrating columns having $H_{\mathrm{c}} / H_{\mathrm{s}}$ ratios of 0.31 and 0.62 and column diameters of $32 \mathrm{~mm}$ and $38 \mathrm{~mm}$ respectively. It is evident that settlement reduces as the depth of treatment increases for similar values of area replacement ratio. The test data presented in Fig. 7 relate to samples reinforced with a partially penetrating column. Although this does not adhere strictly to the traditional concept of the unit cell configuration, Balaam et al. (1977) have shown that, under these conditions, total settlement can be estimated by summing the individual settlements of the reinforced and unreinforced portions. Neglecting small stress variations at the reinforced and unreinforced boundary caused by stress concentrations at the column base, and assuming that the vertical pressure distribution is reasonably uniform across the entire length of the unreinforced sample, the relevant strains experienced by each component can be linearly interpolated from observations of strain made on the two extreme sample conditions of a fully penetrating reinforced and unreinforced sample. The results yielded good correlation between the measured and predicted settlements using this approach. Small variations are attributed to the different boundary conditions between the samples used to generate settlement predictions:

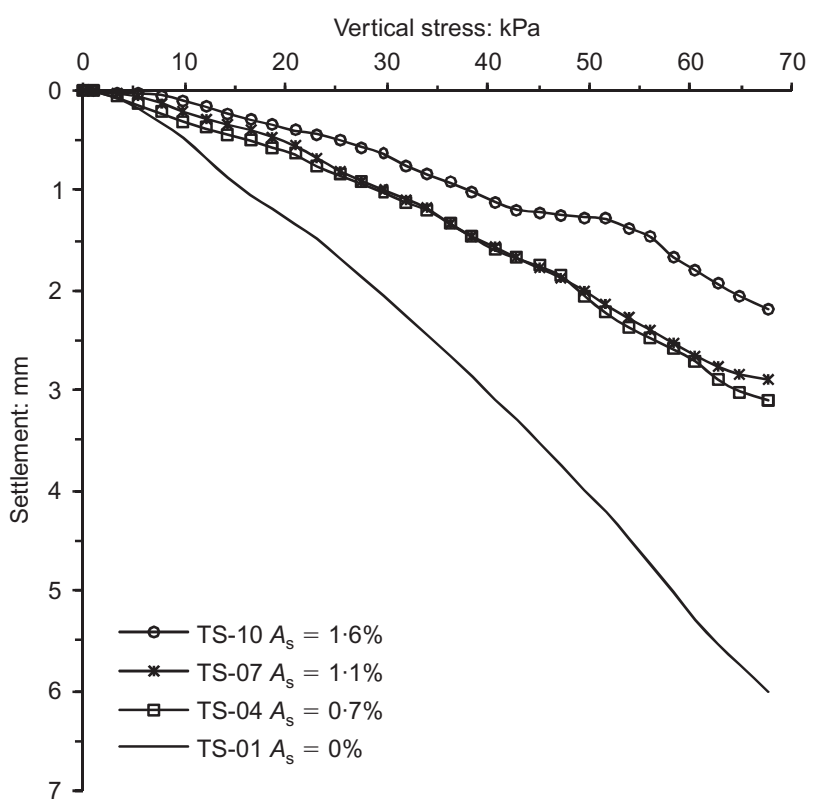

Fig. 6. Settlement under unit cell consideration for $H_{\mathrm{c}} / \boldsymbol{H}_{\mathrm{s}}=1$ with increasing area replacement ratio 


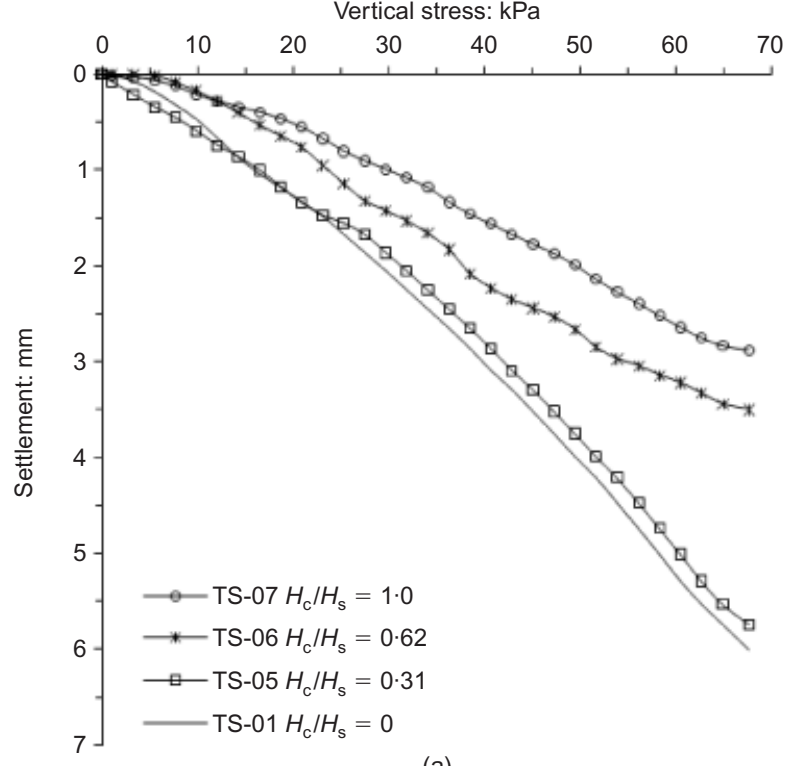

(a)

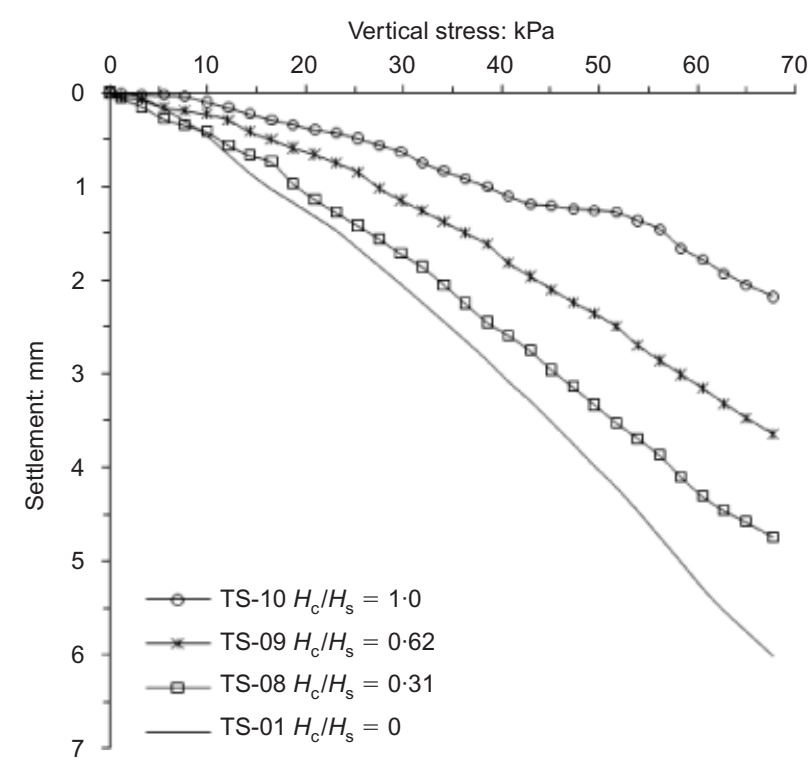

(b)

Fig. 7. Settlement under unit cell consideration with varying area replacement ratio: (a) $A_{\mathrm{s}}=1.1 \%$; (b) $A_{\mathrm{s}}=1.6 \%$

for example, fully rigid restraints were provided by the top plate and pedestal in the extreme conditions, compared with the flexible interface boundary that exists for the partially penetrating condition.

During the apparent $K_{0}$ consolidation, the change in stress acting on the column and surrounding soil beneath the sample top plate was monitored. Fig. 8 displays the results obtained for a sample reinforced with $28 \mathrm{~mm}$ diameter columns of length $125 \mathrm{~mm}, 250 \mathrm{~mm}$ and $400 \mathrm{~mm}$. The increase in vertical stress applied to generate the apparent $K_{0}$ loading was $66 \mathrm{kPa}$ : this agrees well with the uniform increase in stress observed beneath the plate in the unreinforced sample (Fig. 8(a)). However, because of variations in stiffness characteristics in the reinforced specimens, the stress increase measured on the column (PT1) and surrounding clay (PT3) varied. In nearly all tests the magnitude of stress on the column was found to increase with respect to area replacement ratio and column length: this is highlighted for TS-02 to TS-04 in Figs $8($ b) $-8(d)$. Furthermore, as the magnitude of the vertical stress increase on the clay during the apparent $K_{0}$ consolidation was lower than originally intended, some degree of lateral contraction would be anticipated as the horizontal confining stress increased at the previous predetermined rate. This shows good correlation with the lateral displacement measurements recorded at the sample boundary shown in Fig. 5, and with other tests within the series.

Performance of foundation reinforced by a single column State of the composite sample prior to foundation loading. Figure 8 highlighted the stress variation on the column and clay beneath the rigid plate during the apparent $K_{0}$ consolidation stage. If the stress concentration on the column were to be significant during this phase, then frictional resistance might have mobilised prior to application of the actual foundation loading. Mobilisation of strength occurs predominantly as a result of differential displacement; however, internal compression of the granular material along the column length maintains displacement compatibility with the consolidating clay. Consequently it is most probable that mobilisation of strength will be more prevalent where the column is floating, where discontinuity could occur as a result of the column penetrating into the underlying soft clay. The maximum difference in the stress recorded between the column and the soil beneath the top plate was approximately $120 \mathrm{kPa}$ (Fig. 8(c)). It is this stress variation that may contribute to the possible mobilisation of shear strength; however, based on the column geometry, it can be shown that a pressure difference of approximately $600 \mathrm{kPa}$ is required for full mobilisation of the side friction. Since the maximum observed measurement is significantly less, it can be concluded that side friction and end bearing were not mobilised in any significant way prior to the main loading. Similar findings were observed for the $32 \mathrm{~mm}$ and $38 \mathrm{~mm}$ diameter partially penetrating columns.

Further evidence to substantiate the above argument is observed in Fig. 9, which presents the contact stress measured with respect to the vertical displacement throughout the entire three stages of loading (isotropic compression, apparent $K_{0}$ and foundation loading). It is clear that there is no evidence to suggest any significant mobilisation of capacity at the end of the apparent $K_{0}$ stage; however, it can be said that the column was, to some extent, 'prestressed'. This occurrence is not unlike the full-scale application, as the compaction process during installation often results in the column being prestressed.

Settlement reduction. The ultimate undrained bearing capacity for the $60 \mathrm{~mm}$ diameter footing was determined to be $320 \mathrm{kPa}$. Assuming a factor of safety of 2, the allowable bearing capacity is $160 \mathrm{kPa}$. This pressure conforms to typical working loads for vibro columns in practice, and therefore it is an appropriate stress level for the evaluation settlement performance in the model tests.

During the isolated foundation loading stage, the column diameters adopted represent area replacement ratios of $17 \%$, $28 \%$ and $40 \%$ beneath the footing diameter of $60 \mathrm{~mm}$. Fig. 10(a) shows the relationship between bearing pressure and settlement for $A_{\mathrm{s}}=17 \%$ at $H_{\mathrm{c}} / H_{\mathrm{s}}$ ratios of $0.31,0.62$ and $1 \cdot 0$, for tests TS-02, TS-03 and TS-04 respectively. Similar figures for $A_{\mathrm{S}}=28 \%$ and $A_{\mathrm{S}}=40 \%$ are shown in Figs $10(\mathrm{~b})$ and $10(\mathrm{c})$. While noting that increasing the column length resulted in enhanced load-carrying capacity, the settlement at a bearing pressure of $160 \mathrm{kPa}$ was the main focus of the present work and discussion in this paper. The relevant 
Pressure: $\mathrm{kPa}$

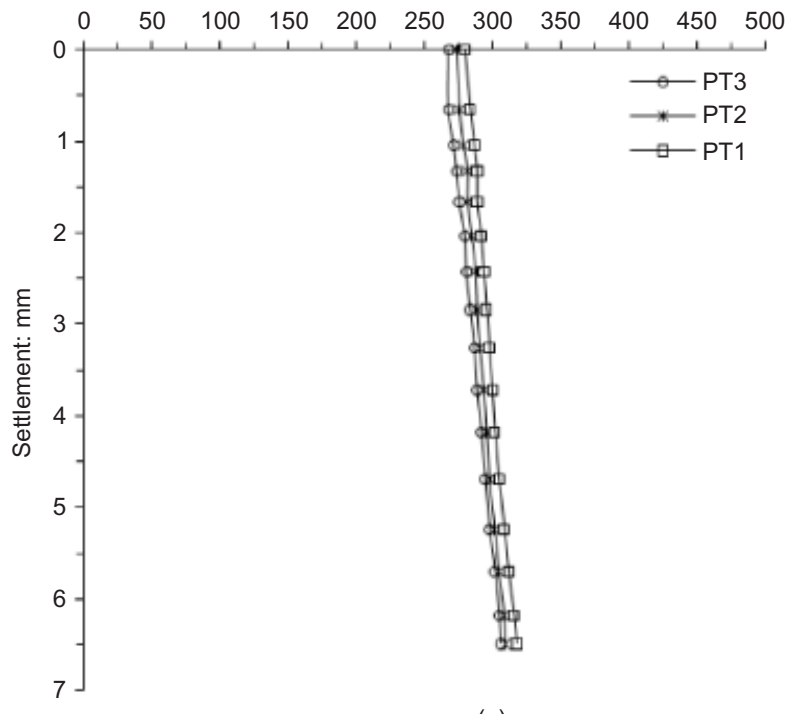

(a)

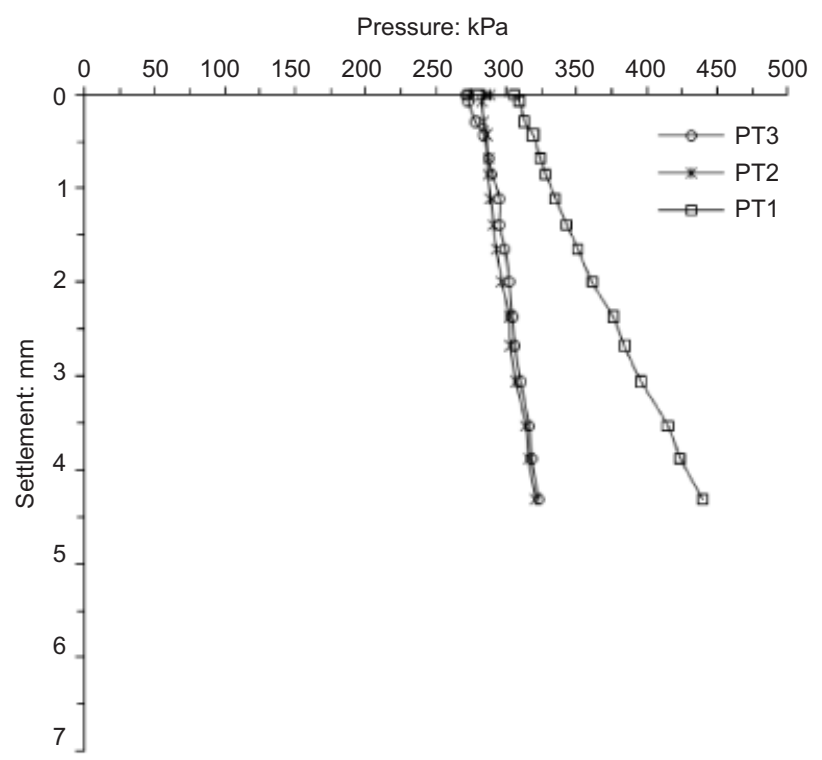

(c)
Pressure: kPa

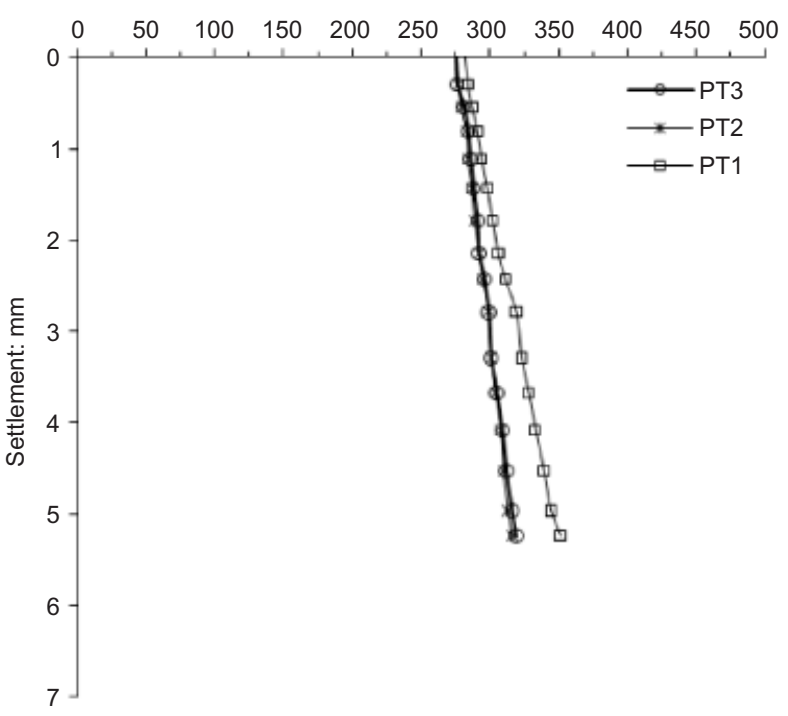

(b)

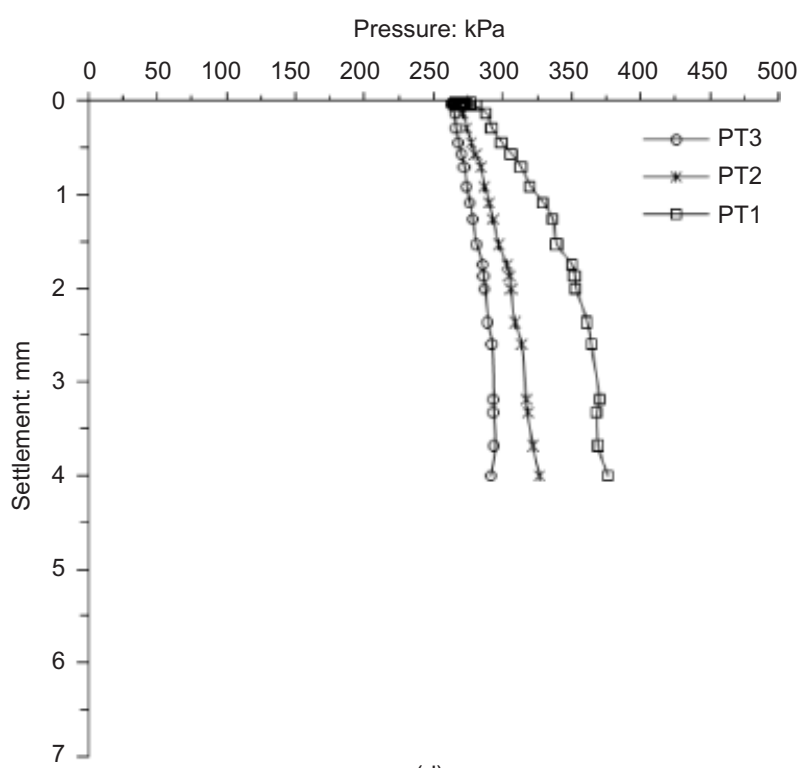

(d)

Fig. 8. Total pressure distribution recorded at locations PT1, PT2 and PT3 for total plate displacement during isotropic compression and $K_{0}$ loading for: (a) unreinforced sample (TS-01), and sample reinforced with $25 \mathrm{~mm}$ diameter column of increasing length; (b) $H_{\mathrm{c}} / H_{\mathrm{s}}=0.31$ (TS-02); (c) $H_{\mathrm{c}} / H_{\mathrm{s}}=0.62$ (TS-03); (d) $H_{\mathrm{c}} / H_{\mathrm{s}}=1$ (TS-04)

settlements and corresponding settlement improvement factors are provided in Table 3. The settlement improvement factor is also plotted with respect to $L / d$ ratio for all values of $A_{\mathrm{S}}$ in Fig. 11(a). It is evident that $n$ increases with respect to $L / d$ ratio for each area replacement ratio, although it appears that increasing the column geometry beyond $L /$ $d=8-10$ offers little significant improvement, particularly at lower $A_{\mathrm{S}}$ values of $17 \%$ and $28 \%$. This agrees favourably with findings previously published by McKelvey (2002), who postulated a critical $L / d$ ratio of 6 in relation to bearing capacity performance for physical model tests. More enhanced improvement in $n$ was observed at $A_{\mathrm{s}}=40 \%$ when $L / d$ exceeded 8 , although the relative rate of increase also diminishes with increasing $L / d$.

The settlement improvement factors are also plotted with respect to area replacement ratio in Fig. 11(b). It is evident that the settlement improvement factor increases with area replacement ratio in a significant manner; however, there appears to be a threshold $A_{\mathrm{s}}$ level for improvement of between $30 \%$ and $40 \%$, particularly when the column is non-end-bearing. This is consistent with observations reported by Wood et al. (2000) for a large-group configuration. When compared with predicted values of $n$ from Priebe (1995) in Fig. 12, it is evident that the observed experimental results are somewhat higher than expected. A possible explanation for this could be the confinement provided as a consequence of the rigid nature of the surcharge boundary condition provided by the sample top plate.

Figures 13(a)-(c) highlight the change in pressure measured by PT1 during the foundation loading stage for each area replacement with increasing $H_{\mathrm{c}} / H_{\mathrm{s}}$ ratio. It can be seen that the change in pressure above the column (PT1) was significantly influenced by the column length. For all values of $A_{\mathrm{s}}$ there appears to be no significant difference between the pressure observed at PT1 for the unreinforced sample and that for the sample reinforced with a $125 \mathrm{~mm}$ 


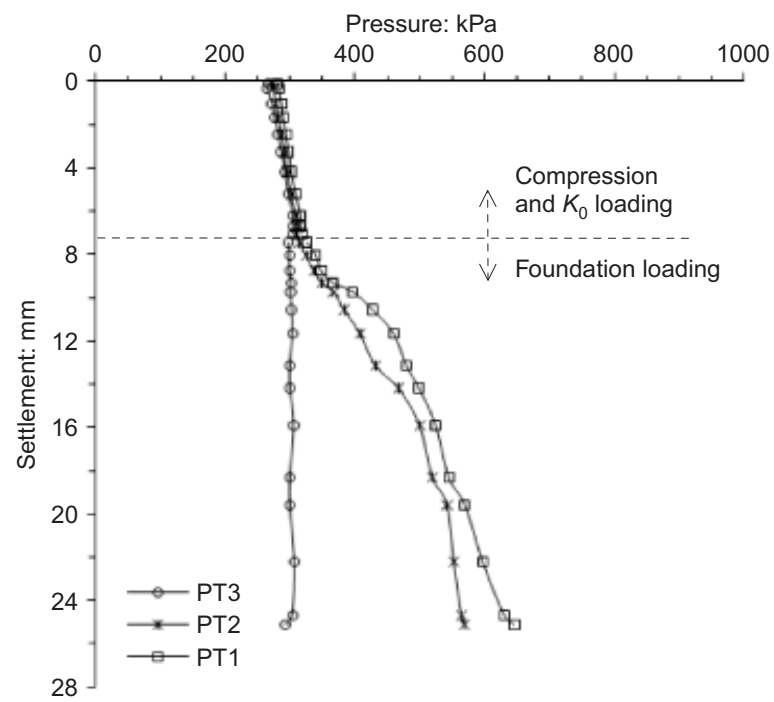

(a)

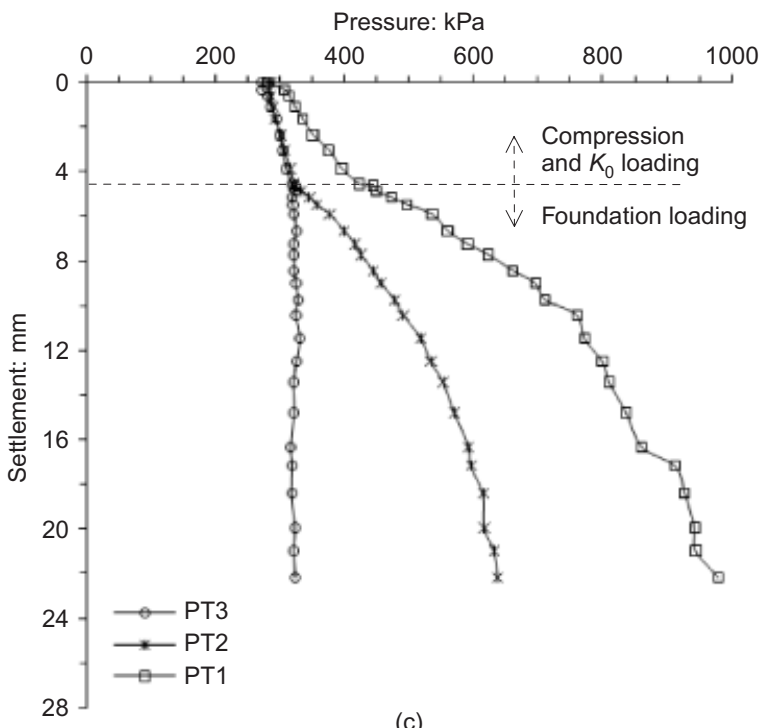

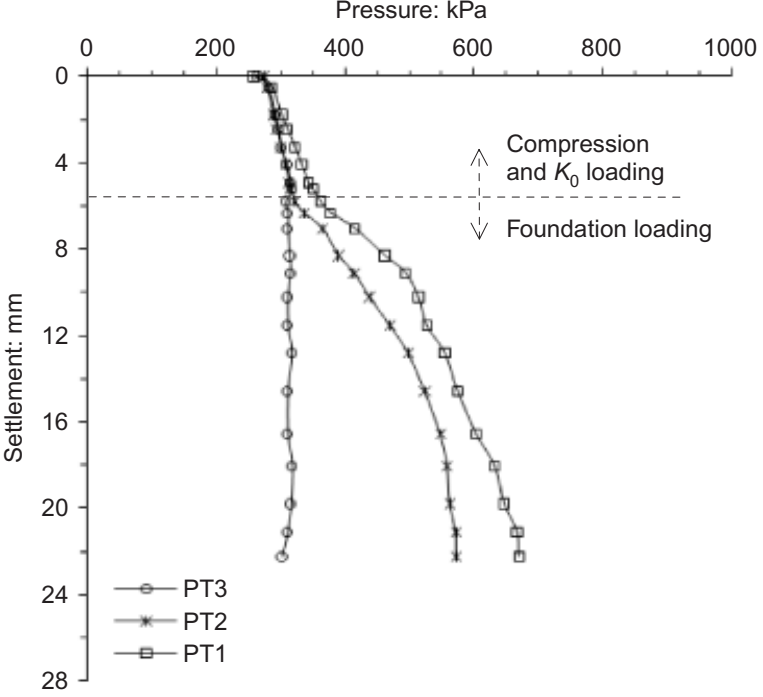

(b)

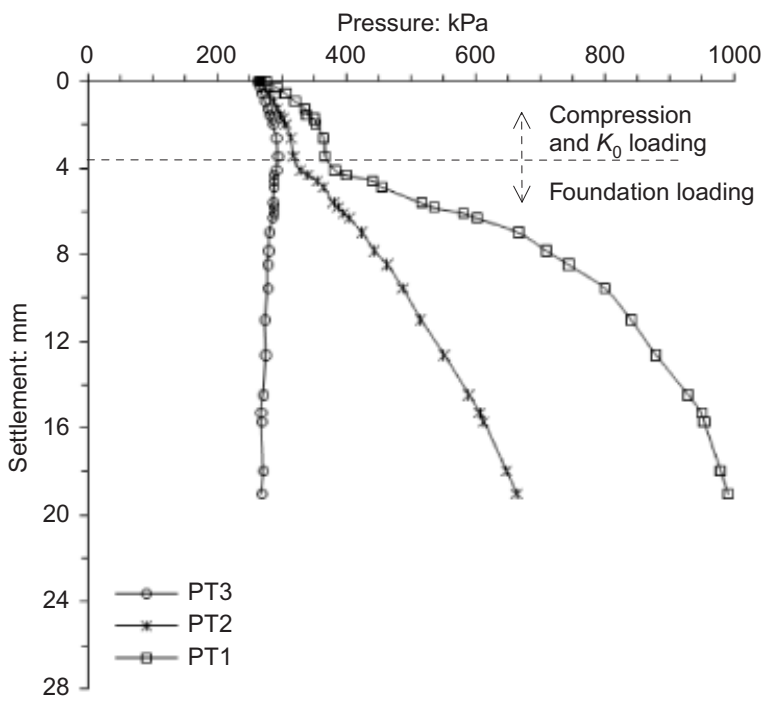

(d)

Fig. 9. Total pressure distribution recorded at locations PT1, PT2 and PT3 during isotropic compression, $K_{0}$ loading and foundation loading for: (a) unreinforced sample (TS-01), and sample reinforced with $\mathbf{2 5} \mathbf{~ m m}$ diameter column of increasing length; (b) $H_{\mathrm{c}} / H_{\mathrm{s}}=0.31$ (TS-02); (c) $H_{\mathrm{c}} / H_{\mathrm{s}}=0.62$ (TS-03); (d) $H_{\mathrm{c}} / H_{\mathrm{s}}=1$ (TS-04)

column $\left(H_{\mathrm{c}} / H_{\mathrm{s}}=0 \cdot 31\right)$. This implies that the shorter column may be acting as a rigid friction pile, and is exhibiting 'end bearing' failure and consequently not contributing significantly towards the load capacity or mitigating settlement. Larger pressure differences at PT1 were recorded once the column geometry $(L / d)$ exceeded the critical length and are attributed to greater column capacity arising from bulging.

The lateral displacements observed during foundation loading at $120 \mathrm{~mm}$ below the top plate are reported for tests TS-01, TS-02 and TS-03 in Fig. 14(a) for $A_{\mathrm{S}}=17 \%$. For the short column $\left(H_{\mathrm{c}} / H_{\mathrm{s}}=0.31\right)$, the sample contracted laterally in the early stage of the loading (up to a displacement of $6.5 \mathrm{~mm}$ ) by $0.022 \mathrm{~mm}$, and this was followed by continued expansion as the loading continued. The maximum radial expansion at the termination of loading was $0.038 \mathrm{~mm}$. The initial contraction and reduced radial expansion observed in this case further substantiate the hypothesis, based on the variation of pressure, that shorter columns behaved as load transfer elements, and failed in end bearing. For the longer column $\left(H_{\mathrm{c}} / H_{\mathrm{s}}=0 \cdot 62\right.$, representing an $L / d$ ratio of 10$)$, greater expansion of the reinforced sample than in the unreinforced condition was recorded. Column bulging would be more a predominant failure mechanism, and the lateral displacement measurements support this. Similar findings relating to sample contraction and expansion were also observed for $A_{\mathrm{S}}=28 \%$ and 40\% (Figs 14(b) and Fig. 14(c) respectively).

Further confirmation of column failure modes was also obtained from the deformed column profiles observed by sample dissection after each test (Fig. 15). It is shown in Fig. 16 that the base displacement of the column decreases with increasing column $L / d$, is negligible for $L / d>8$, and disappears completely at $L / d \approx 10$. Furthermore, in TS-02 and TS-05 the magnitude of base displacement observed is $50 \%$ of the final foundation displacements of $15.9 \mathrm{~mm}$ and $12.5 \mathrm{~mm}$ respectively. This increases considerably in TS-08 to almost $90 \%$, which again emphasises that short columns with low $L / d$ ratio failed in end bearing, despite the occurrence of some internal column compression. 


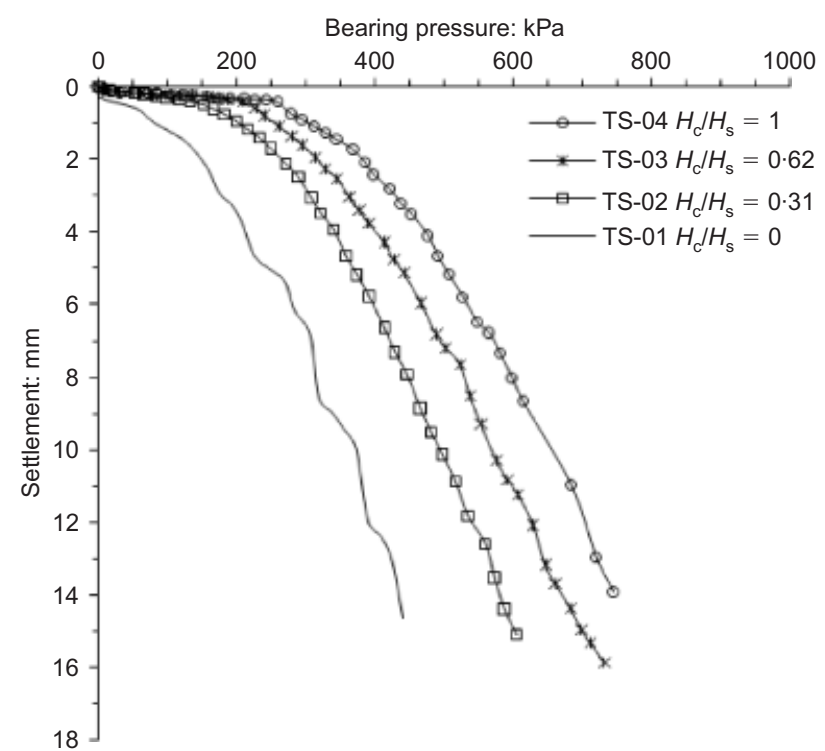

(a)

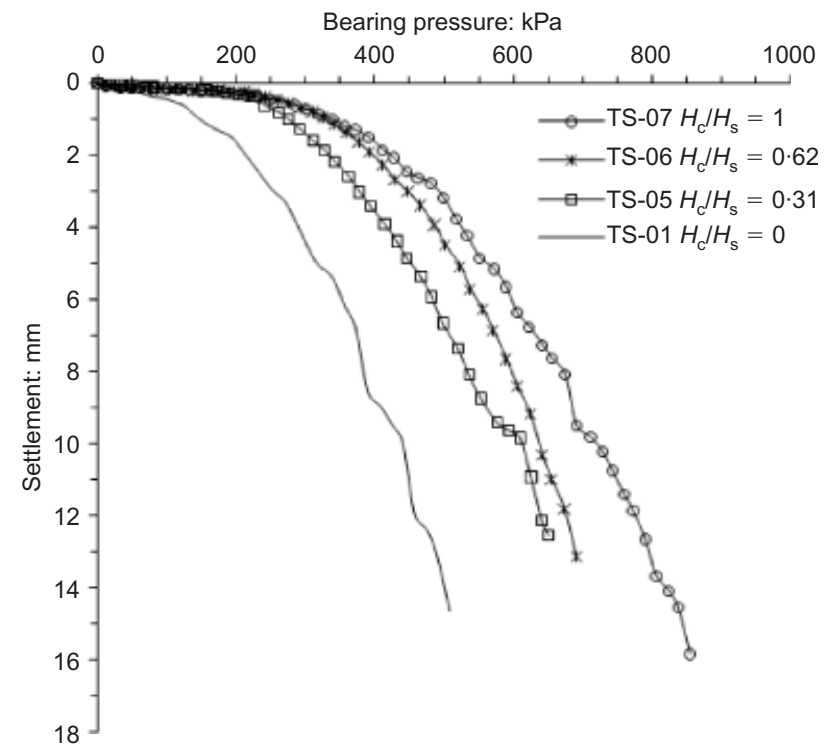

(b)

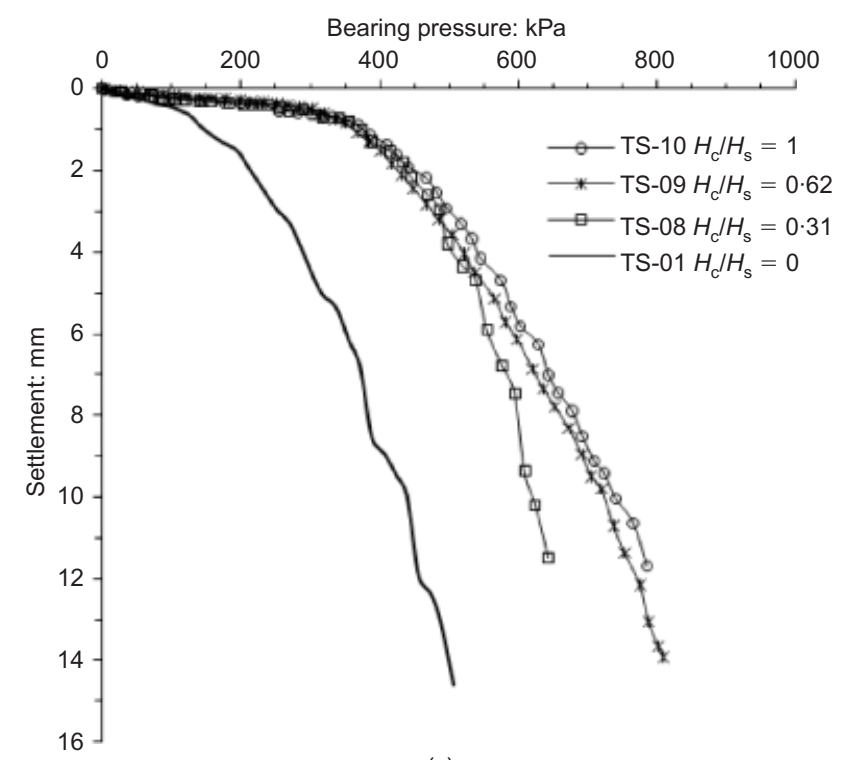

(c)

Fig. 10. Footing pressure-settlement response of sample reinforced with columns of various area replacement and $H_{\mathrm{c}} / \boldsymbol{H}_{\mathrm{s}}$ ratios: (a) $A_{\mathrm{s}}=17 \%$; (b) $A_{\mathrm{s}}=28 \%$; (c) $A_{\mathrm{s}}=40 \%$
Table 3. Settlement improvement factor during foundation loading

\begin{tabular}{l|c|c}
\hline Test no. & Settlement: $\mathrm{mm}$ & Improvement factor, $n$ \\
\hline TS-01 & $1 \cdot 50$ & $1 \cdot 00$ \\
TS-02 & $0 \cdot 40$ & $3 \cdot 75$ \\
TS-03 & $0 \cdot 28$ & $5 \cdot 36$ \\
TS-04 & $0 \cdot 26$ & $5 \cdot 77$ \\
TS-05 & $0 \cdot 23$ & $6 \cdot 49$ \\
TS-06 & $0 \cdot 22$ & $6 \cdot 82$ \\
TS-07 & $0 \cdot 21$ & $7 \cdot 14$ \\
TS-08 & $0 \cdot 29$ & $5 \cdot 24$ \\
TS-09 & $0 \cdot 23$ & $6 \cdot 52$ \\
TS-10 & $0 \cdot 20$ & $7 \cdot 50$ \\
\hline
\end{tabular}

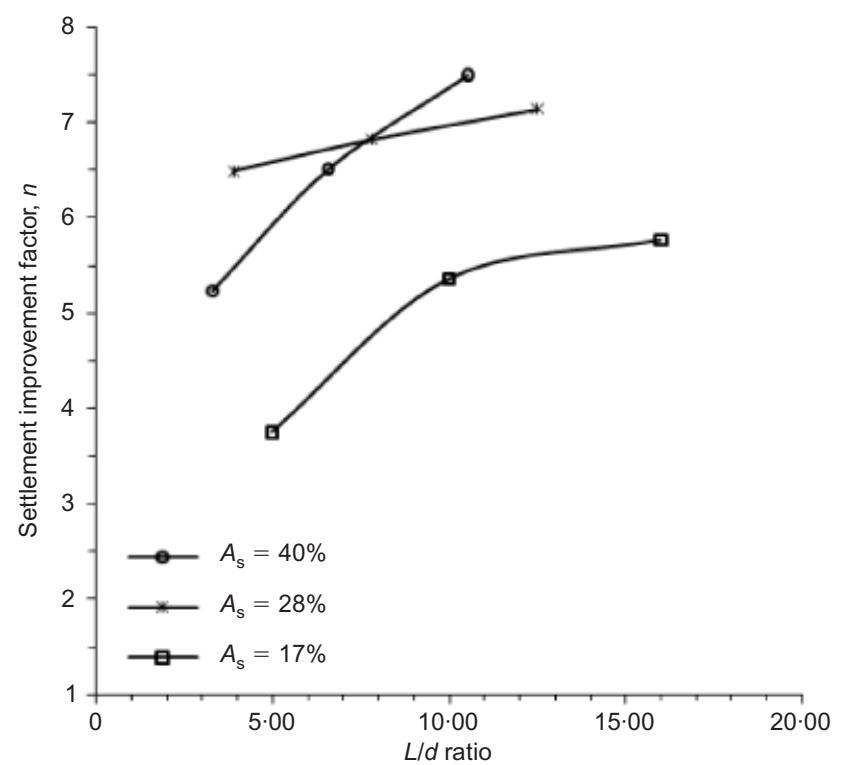

(a)

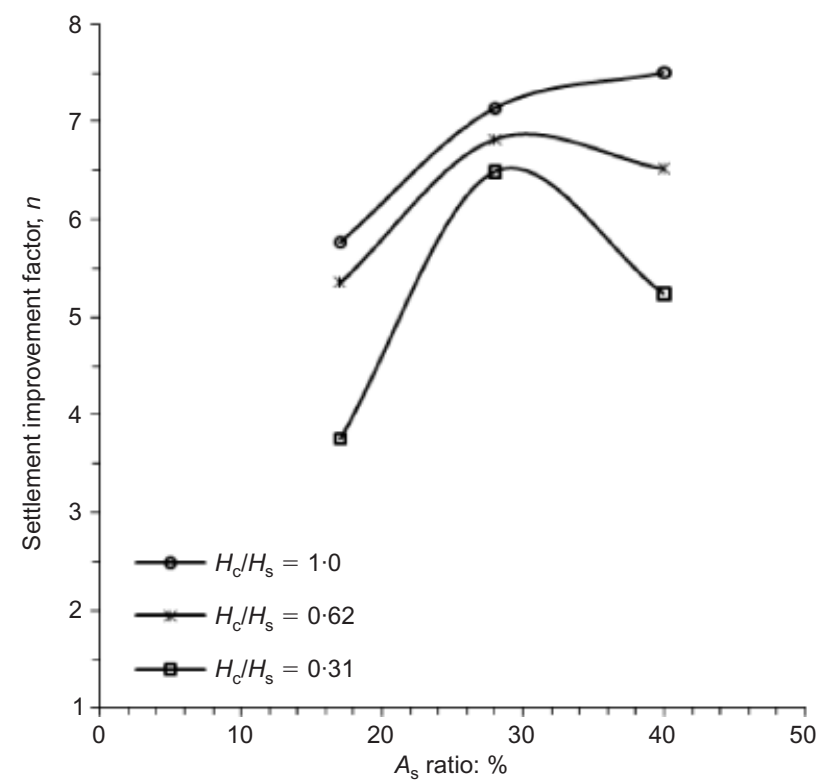

(b)

Fig. 11. Settlement improvement factor plotted against: (a) $L / d$ ratio; (b) $A_{\mathrm{s}}$ ratio 


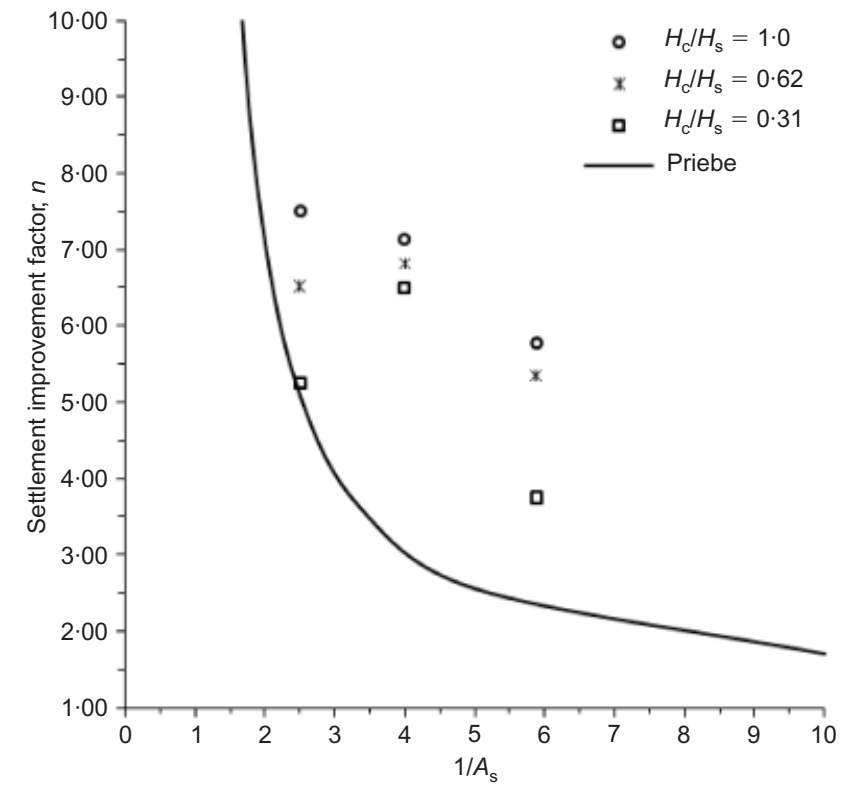

Fig. 12. Settlement improvement factor compared with that of Priebe (1995)

Performance of foundations supported on column groups

The performance of a small group of three columns, $18 \mathrm{~mm}$ and $22 \mathrm{~mm}$ in diameter (corresponding to $A_{\mathrm{S}}=28 \%$ and $40 \%$ ) and $250 \mathrm{~mm}$ and $400 \mathrm{~mm}$ long, were evaluated using the same test configuration as described above. Fig. 17(a)-(d) presents the pressure-settlement characteristics for the small-group configuration, compared with that of the corresponding single column at matching $A_{\mathrm{s}}$ and length. The overall load-carrying capacity of the foundation supported on the group of columns is generally similar to that of a single column at the same area replacement ratio, with the exception of small variations at low bearing pressures. The settlement of the foundation at the target bearing pressure (160 $\mathrm{kPa})$ for the group $A_{\mathrm{s}}=28 \%$ and $40 \%$ at $H_{\mathrm{c}} / H_{\mathrm{s}}=0.62$ is $0.46 \mathrm{~mm}$ and $0.39 \mathrm{~mm}$ respectively, which represents settlement improvement factors of 3.2 and 3.8 . These $n$ values, and those determined for $H_{\mathrm{c}} / H_{\mathrm{s}}=1 \cdot 0$ in the group configuration, are plotted in Fig. 18. For direct comparison the corresponding single-column $n$ values are also included. It is evident that the performance of the group is not as good as that of the corresponding single column, and it is interesting that this reduction is more significant when the column is not end bearing.

The effect of block failure arising due to group interaction is well documented in relation to pile foundations (Poulos, 1968; Poulos \& Mattes, 1974; Meyerhof, 1976). Examination of the excavated column profiles showed that similar behaviour is prevalent in partially penetrating groups of stone columns $\left(H_{\mathrm{c}} / H_{\mathrm{s}}=0 \cdot 62\right)$. Redefining the $L / d$ ratio to account for group behaviour by replacing the individual column diameter $(d)$ with that of the effective group diameter $\left(d_{\mathrm{g}}=60 \mathrm{~mm}\right)$ produces revised $L / d_{\mathrm{g}}$ ratios for the group configuration at $A_{\mathrm{s}}=28 \%$ and $40 \%$ of 4 and 6 respectively. These values are similar to the critical column length previously defined for a single column condition by Hughes \& Withers (1974) and McKelvey (2002). Lateral contraction of the sample boundary for the partially penetrating column group $\left(H_{\mathrm{c}} / H_{\mathrm{s}}=0.62\right)$, similar to that previously described for the isolated column, provides additional supporting evidence to support the block failure mechanism observations.

Figure 19 shows the pressure recorded by PT1 and PT2 during the foundation loading for TS-12 and 14. Under

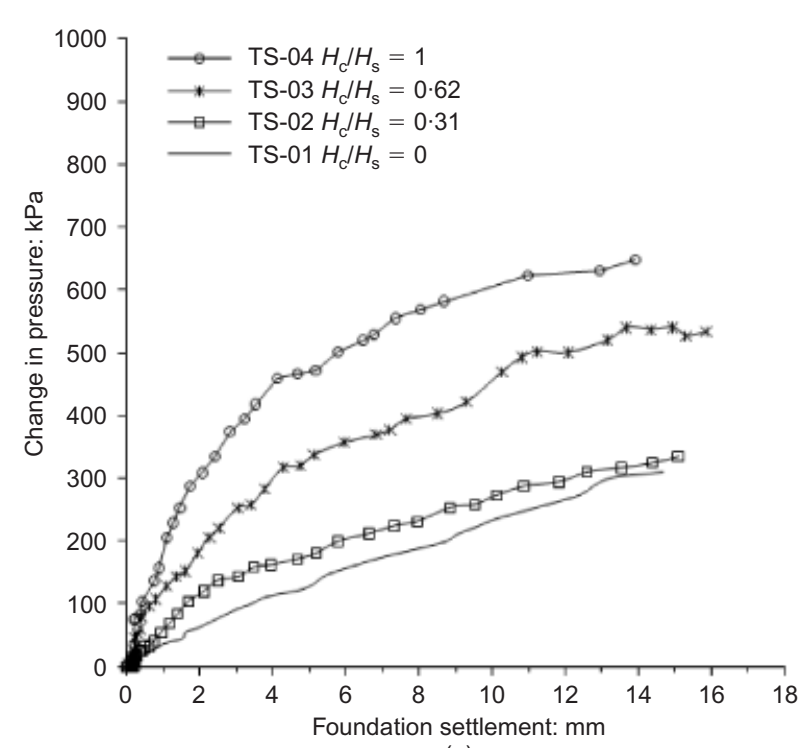

(a)

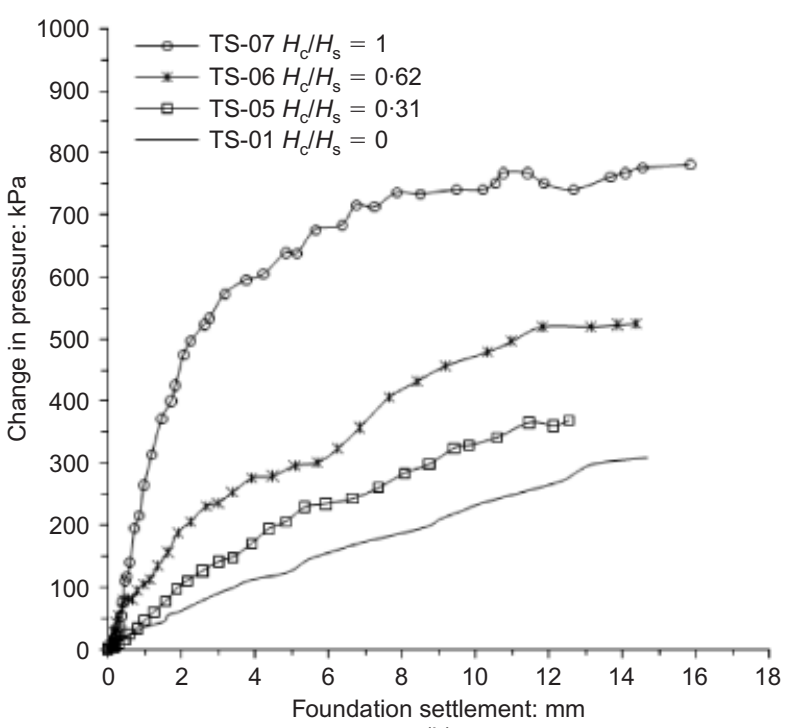

(b)

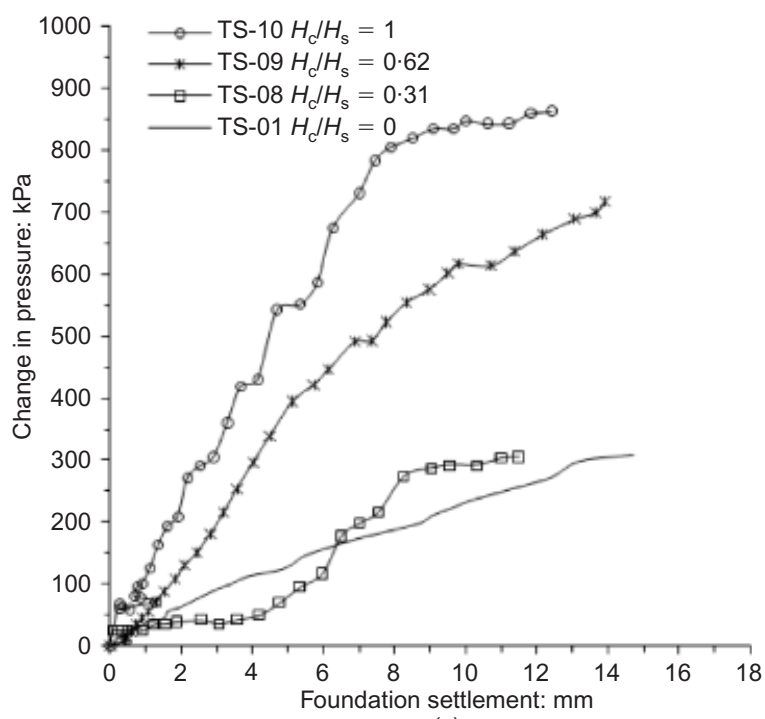

(c)

Fig. 13. Change in pressure at column location recorded by PT1: (a) $A_{\mathrm{s}}=17 \%$; (b) $A_{\mathrm{s}}=28 \%$; (c) $A_{\mathrm{s}}=40 \%$ 


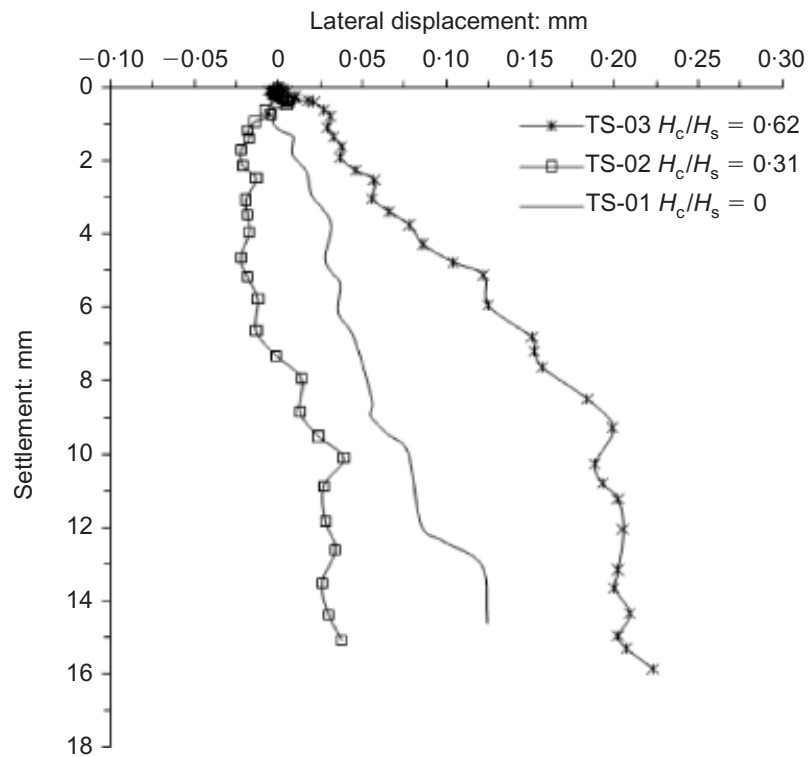

(a)

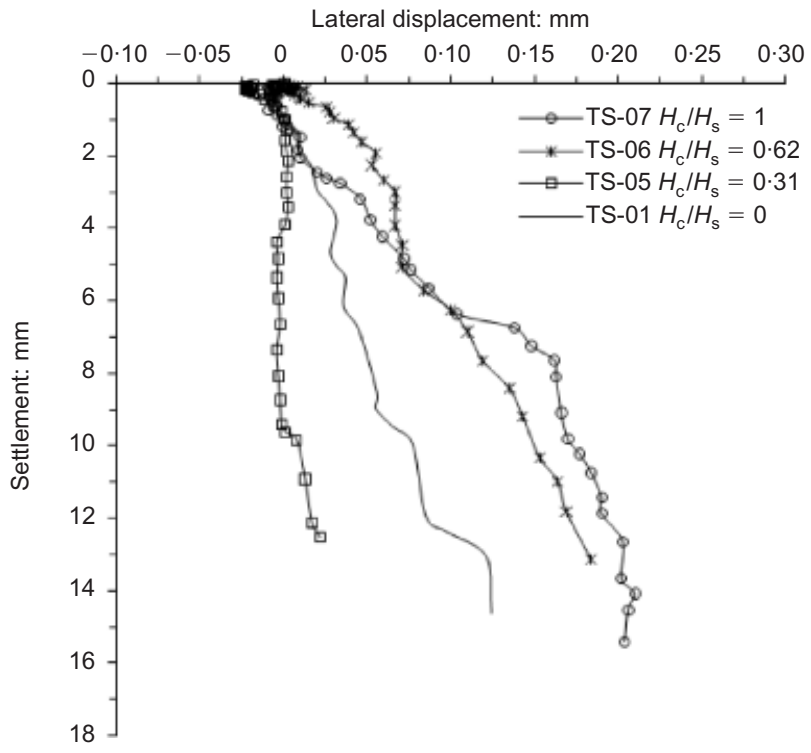

(b)

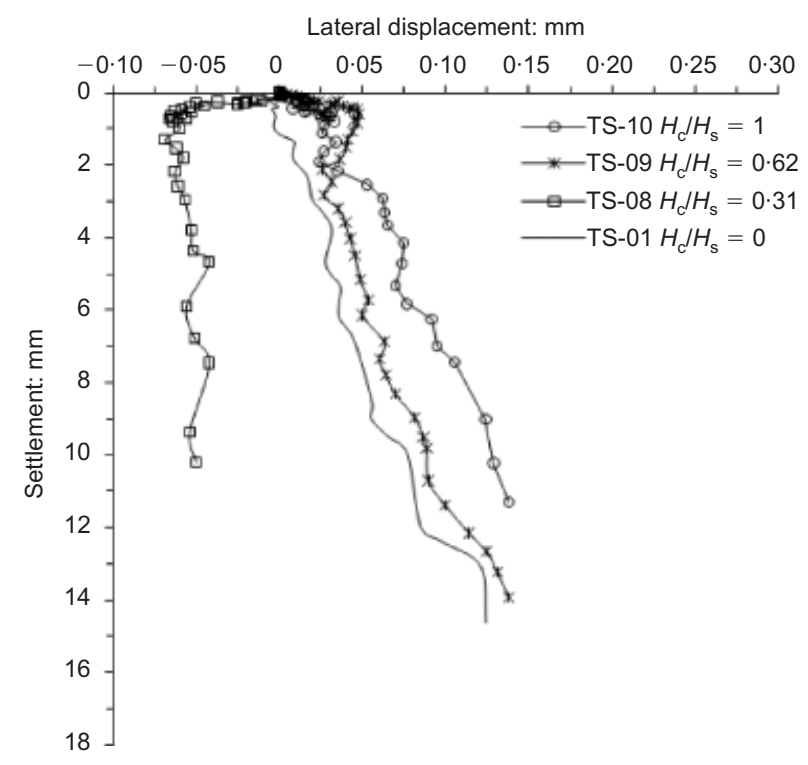

(c)

Fig. 14. Lateral strain response during foundation loading: (a) $A_{\mathrm{s}}=17 \%$; (b) $A_{\mathrm{s}}=28 \%$; (c) $A_{\mathrm{s}}=40 \%$ group conditions, PT1 is now exposed to clay and PT2 is exposed to the stone column. The pressure recorded by PT1 is significantly higher than the pressure read by PT2; although this may be counterintuitive, based on the relative material stiffness, this particular observation can be explained by the load-carrying mechanism of stone columns. Upon loading, stone columns may undergo deformation, as they are non-rigid elements. As evidenced through sample dissection after loading in both this and previous research (Hu, 1995; McKelvey, 2002), column bulging and subsequent inter-column interactions have a significant role in controlling group stability. Enhanced lateral resistance of the clay in the central confined clay region provides improved support against column deformation, which reduces the bulging observed on the inner column surfaces. Deformations occur more readily on the outward surfaces, as the lateral pressures and soil confinement are lower beyond the edge of the foundation. As footing displacement progresses, the lateral pressure on the internal face will continue to increase, therefore generating column bending towards the weaker unsupported side.

\section{Settlement control using stone columns}

The research considered various aspects of the stone column application, which includes the area replacement ratio, $L / d$ ratio, and small-group performance. A finding from the research is the possible existence of a threshold area replacement ratio of between $30 \%$ and $40 \%$ for settlement performance. However, it is acknowledged that this observation is currently only related directly to the test configuration, and may be not valid as a general rule in all cases, because of variations in soil shear strength and stiffness. Furthermore, it was noted that enhanced performance of the column can be achieved if the tendency to bulging is restricted. For moderate area replacement ratios the clay annulus beneath the foundation surrounding the column is also subjected to increased vertical stress for the foundation load, and hence is able to provide enhanced lateral restraint against bulging. This beneficial effect is dependent on the thickness of the annulus, and when this is significantly reduced (as in the case of larger $A_{\mathrm{S}}$ values), the overall column performance is compromised, as bulging failure occurs more readily. Similar behaviour could also contribute to the relatively reduced performance of the group as the columns were located at the edge of the footing.

From the load-displacement curves presented in Fig. 10 and the settlement improvement factors presented in Fig. 11 it is shown that there may be evidence to suggest that some degree of design flexibility exists for the design of stone columns, whereby settlement can be effectively controlled when using larger area replacement ratios and relatively short column lengths $(L / d<6)$ or long, slender columns $(L / d>6)$ at relatively small area replacement values. The authors acknowledge that this hypothesis is at present based only on limited test data; however, continued research in this respect may offer more conclusive evidence in order to substantiate the above argument fully. Nevertheless, the potential of such a finding would be invaluable in the design of stone columns in difficult site conditions, as it would allow greater flexibility in the column geometry for the treatment provided, in addition to providing advanced economic viability of the stone column technique.

The group study revealed that the pressure developed in the clay enclosed by the three columns was significantly higher than in the confining columns, and this contributed to excessive column deformation on the outer surface of the column. This observation leads to an interesting consideration: in practice it is often the case that a central column is 


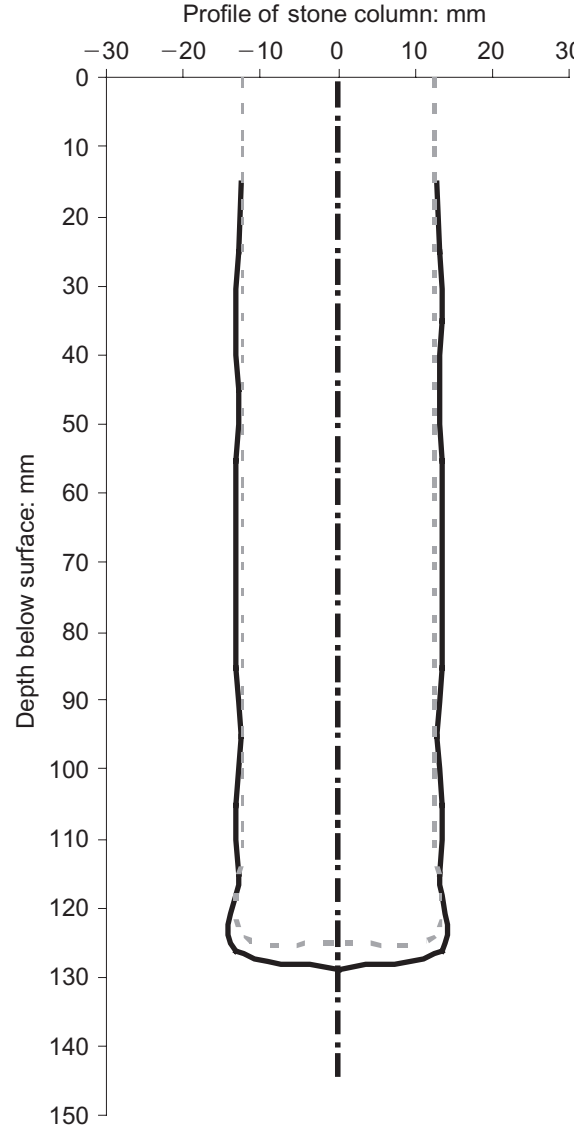

(a)

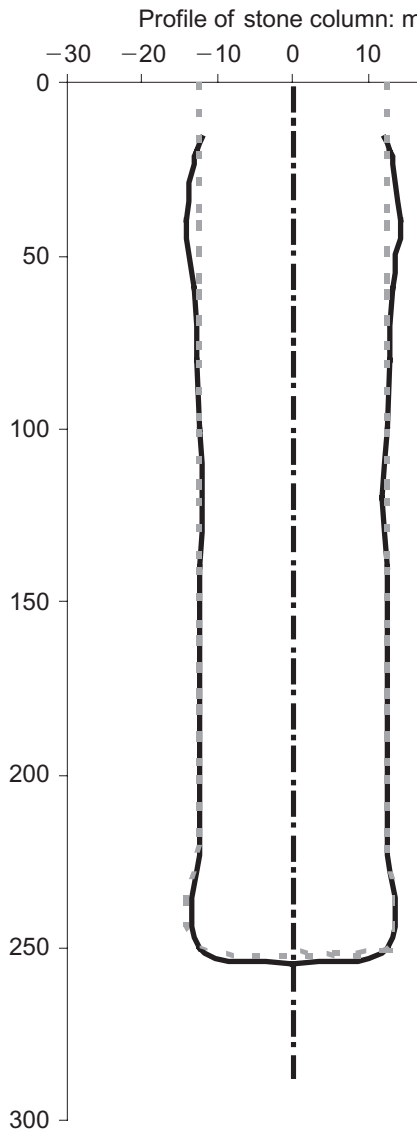

(b)

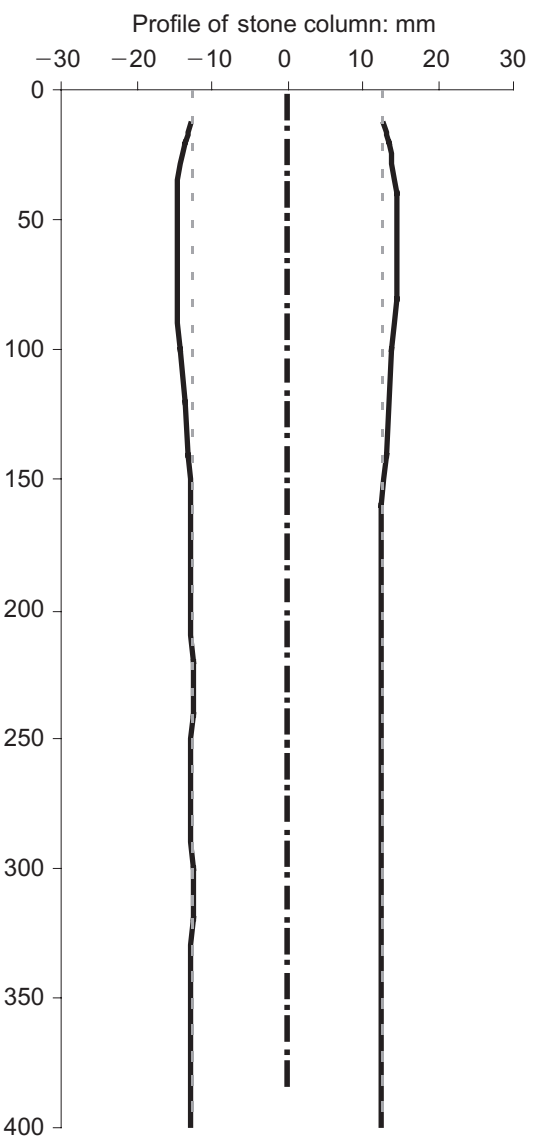

(c)

Fig. 15. Excavated column profile, $A_{\mathrm{s}}=17 \%$ : (a) $L / d=5$; (b) $L / d=10$; (c) $L / d=16$

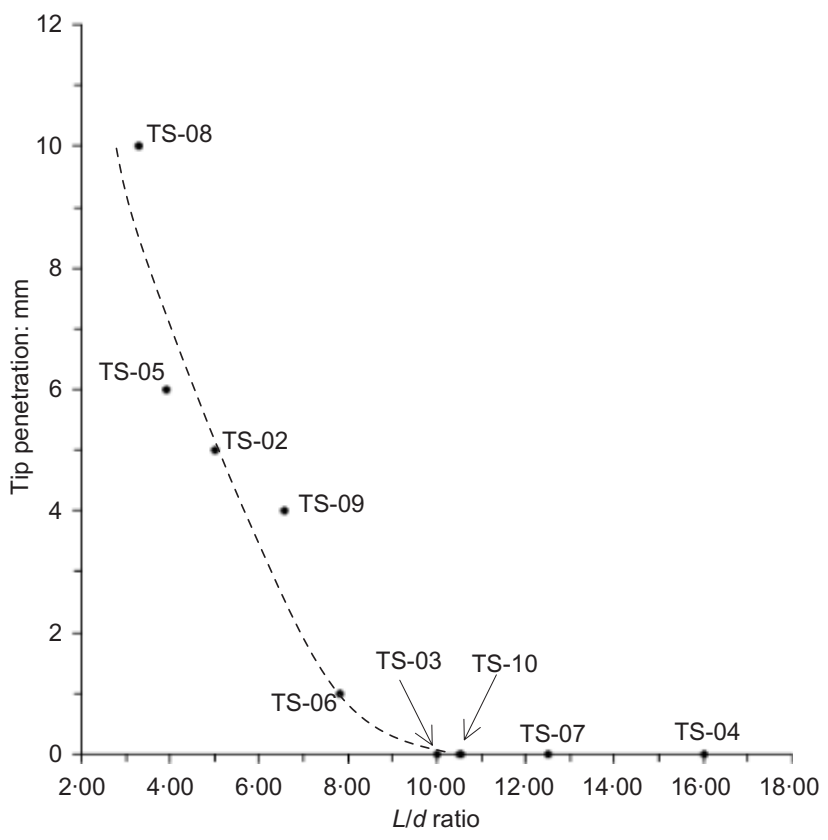

Fig. 16. Column tip penetration plotted against $L / d$ ratio

placed in the middle of a small circular or square column group. Information determined in the present investigations raises questions regarding this configuration, as it may be superfluous to the overall group performance, although further testing is required to substantiate this.

\section{CONCLUDING REMARKS}

The work reported in this paper documented the settlement performance of a $60 \mathrm{~mm}$ foundation supported on soft clay treated with stone columns with different configurations of column length to diameter ratio, area replacement ratio and single/group conditions. It has been observed that settlement can equally be controlled using shorter columns at higher replacement ratios or longer columns at reduced area replacement. In addition, it is also shown that an optimum area replacement ratio of between $30 \%$ and $40 \%$ exists for the control of settlement, and that soil-structure interaction has a significant role in preventing excessive column deformations. The existence of a block mechanism in conjunction with enhanced localised stress in the enclosed soil confined by the small-group configuration proved to have a detrimental effect on settlement when compared with an isolated column. The above findings could make a significant positive contribution to current design practice, although it is acknowledged that additional model and field experiments, coupled with parametric numerical evaluation, are required to verify these conclusions.

\section{ACKNOWLEDGEMENTS}

Funding for the research was provided by DEL and Keller Ground Engineering, UK. The equipment was manufactured by VJ Tech, UK. The authors wish to thank Professor Adrian Hyde for constructive comments during the preparation of this paper. The authors also wish to thank Mr K. V. Senthilkumaran and Mr P. Carey (P. J. Carey Contractors Ltd) for their support of the geotechnical research at Queen's University Belfast. 


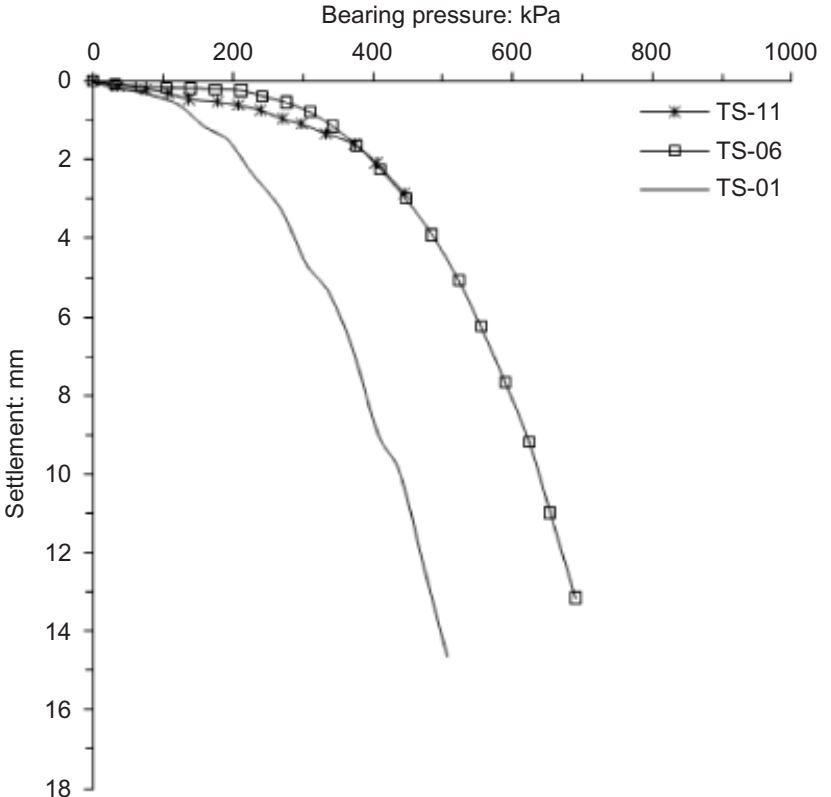

(a)

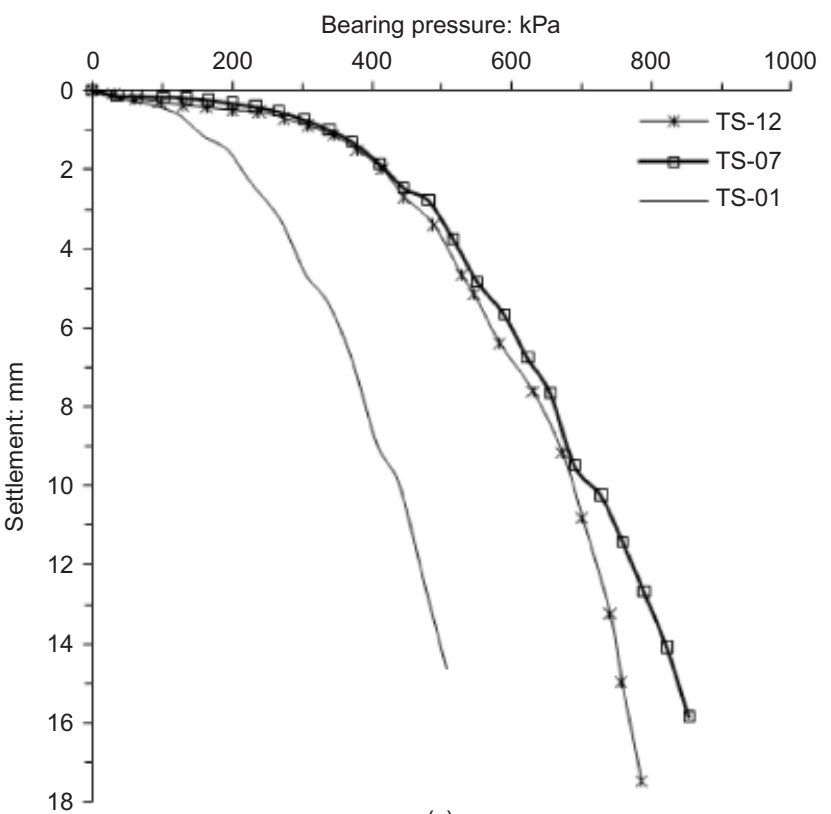

(c)

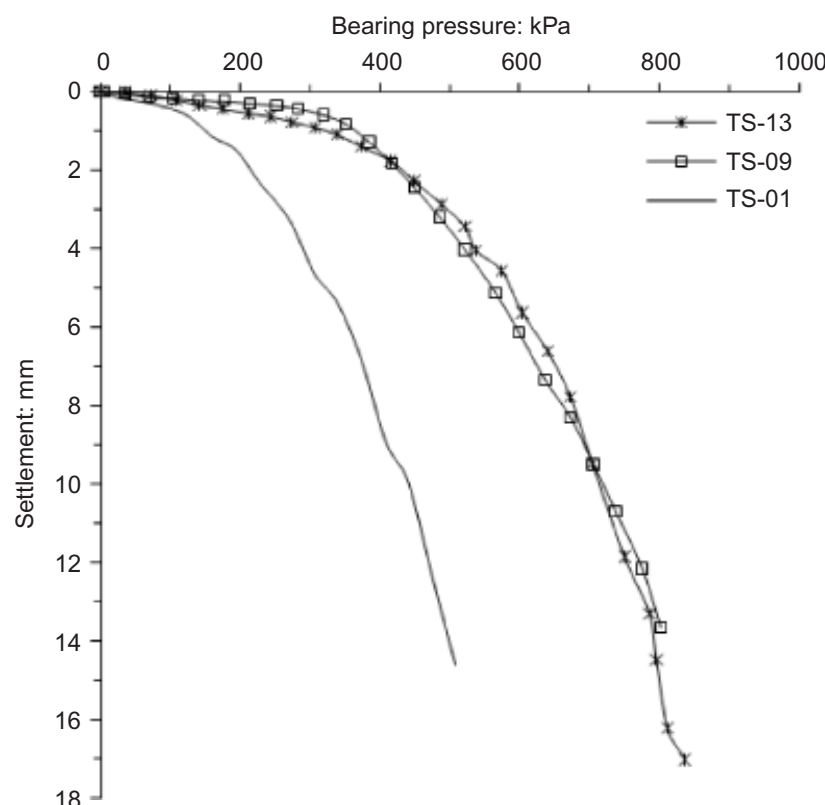

(b)

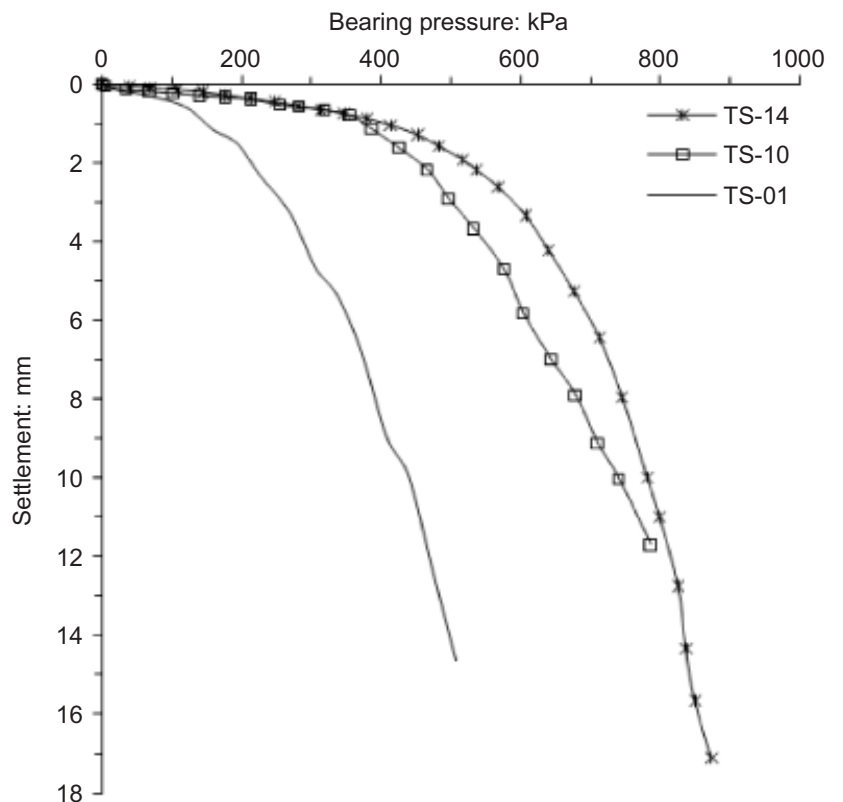

(d)

Fig. 17. Small-group performance compared with isolated column: (a) $A_{\mathrm{s}}=28 \%, H_{\mathrm{c}} / H_{\mathrm{s}}=0 \cdot 62 ; \quad(\mathrm{b}) A_{\mathrm{s}}=28 \%, H_{\mathrm{c}} / H_{\mathrm{s}}=1 \cdot 0 ;$ (c) $A_{\mathrm{s}}=40 \%, H_{\mathrm{c}} / H_{\mathrm{s}}=0.62 ;$ (d) $A_{\mathrm{s}}=40 \%, H_{\mathrm{c}} / H_{\mathrm{s}}=1 \cdot 0$

\section{NOTATION}

$A_{\mathrm{c}}$ area of stone column

$A_{\mathrm{s}}$ area replacement ratio

$B$ foundation breadth

$c_{\mathrm{u}} \quad$ undrained shear strength

$D$ foundation diameter

$d$ stone column diameter

$d_{\mathrm{g}}$ effective stone column group diameter

$e$ void ratio

$E_{\mathrm{s}}, E_{\mathrm{c}}$ deformation moduli of soil and column

$H_{\mathrm{c}} / H_{\mathrm{s}}$ ratio of column length to sample height (soil)

$n$ settlement improvement factor

$K_{0}$ coefficient of earth pressure at rest

$L$ column length

$L / d$ ratio of column length to diameter

$p^{\prime}$ mean effective stress
$Q$ deviator stress

$q_{\mathrm{o}}$ surcharge pressure

$q_{\mathrm{u}} \quad$ ultimate bearing pressure

$S$ settlement

$S_{\mathrm{t}} \quad$ settlement of treated soil

$S_{\text {ut }}$ settlement of untreated soil

$s$ column spacing

$W$ foundation width

$\nu_{\mathrm{S}}^{\prime}$ Poisson's ratio of soil

$\sigma_{\mathrm{rc}}, \sigma_{\mathrm{rs}}$ radial stress in column and soil

$\sigma_{\mathrm{vc}}, \sigma_{\mathrm{vs}}$ vertical stress experienced by column and soil

$\sigma_{\mathrm{v}}^{\prime}, \sigma_{\mathrm{h}}^{\prime}$ vertical and horizontal effective stress

$\sigma_{1}, \sigma_{1}^{\prime}$ vertical total and effective stress

$\sigma_{3}, \sigma_{3}^{\prime}$ horizontal total and effective stress

$\tau$ shear stress

$\phi_{\mathrm{c}}^{\prime}, \phi_{\mathrm{s}}^{\prime}$ friction angle of the column and soil 


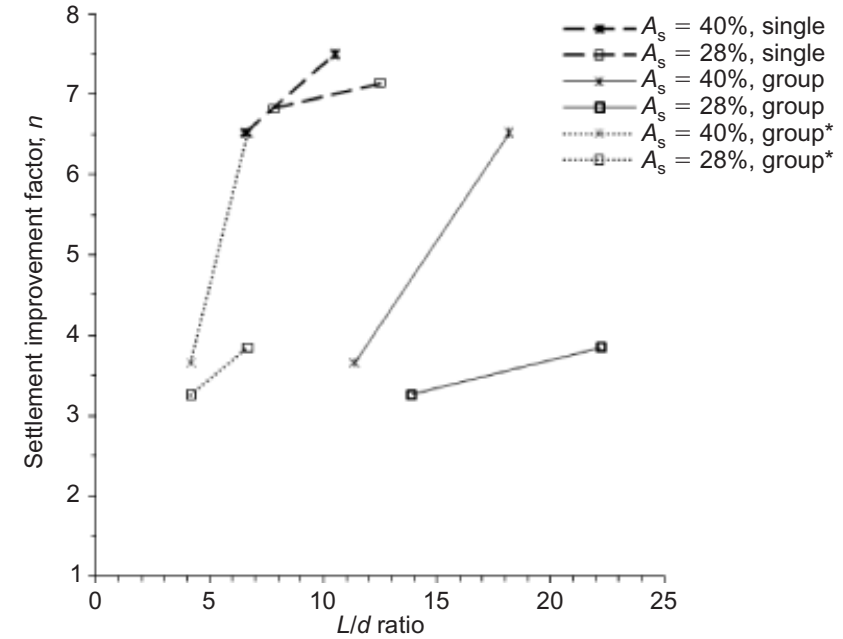

Fig. 18. Settlement improvement factor for single and a group of columns; ${ }^{*}$ denotes $L / d$ based on group diameter, $d_{\mathrm{g}}$

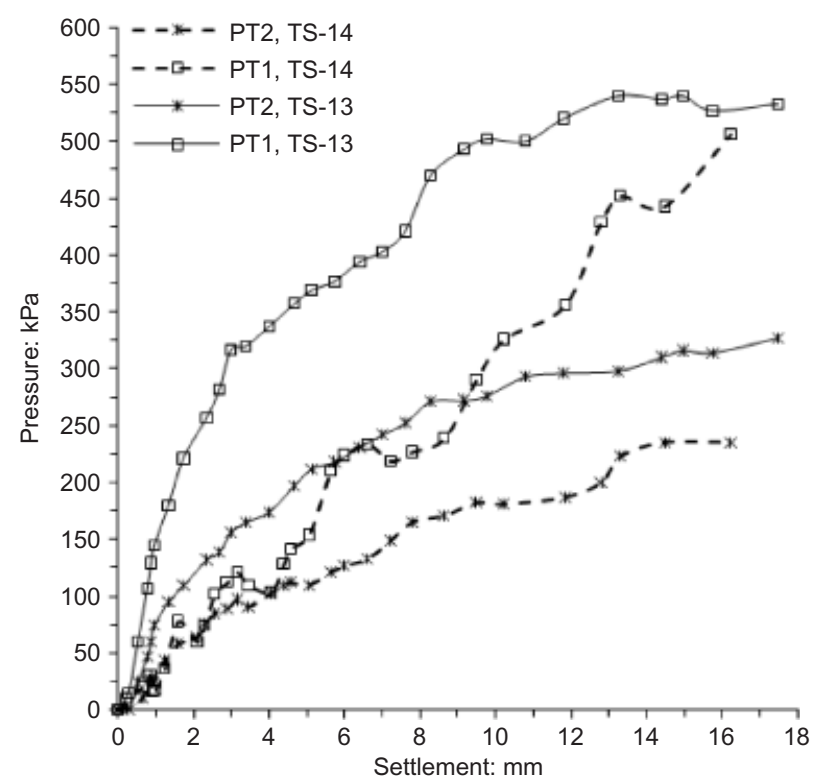

Fig. 19. Pressure recorded beneath footing in group configuration

\section{REFERENCES}

Aboshi, H., Ichimoto, E., Enoki, M. \& Harada, K. (1979). The Compozer method to improve characteristics of soft clays by inclusion of large diameter sand columns. Proceedings of the international conference on soil reinforcement: Reinforced earth and other techniques, Paris, Vol. 1, pp. 211-216.

Ahmadi, M. M. \& Robertson, P. K. (2004). Calibration chamber size and boundary effects for CPT $q_{\mathrm{c}}$ measurements. Proc. 2nd Int. Conf. on Geotechnical and Geophysical Site Characterisation, Porto 1, 829-834.

Alamgir, M., Miura, N. \& Madhav, M. R. (1994). Analysis of stone column reinforced ground. II: Stress transfer from stone column to soil. Reports of the Faculty of Science and Engineering, Saga University, Japan 22, No. 1, 111-118.

Anderson, W. F., Pyrah, I. C. \& Fryer, S. (1991). A clay calibration chamber for testing field devices. Geotech. Test. J. 14, No. 4, 440-450.

Balaam, N. P. \& Booker, J. R. (1981). Analysis of rigid rafts supported by granular piles. Int. J. Numer. Anal. Methods Geomech. 5, No. 4, 379-403.

Balaam, N. P., Poulos, H. G. \& Brown, P. T. (1977). Settlement analysis of soft clays reinforced with granular piles. Proc. 5th Southeast Asian Conf. on Soil Engineering, Bangkok 1, 81-91.
Barksdale, R. D. \& Bachus, R. C. (1983). Design and construction of stone columns, Report No. FHWA/RD-83/026. Springfield, VA: National Technical Information Service.

Black, J. A. (2007). The settlement performance of a footing supported on soft clay reinforced with vibrated stone columns. $\mathrm{PhD}$ thesis, Queen's University of Belfast.

Black, J., Sivakumar, V. \& Madhav, M. (2007a). Reinforced stone columns in weak deposits: laboratory model study. J. Geotech. Geoenviron. Engng ASCE 133, No. 9, 1154-1161.

Black, J., Sivakumar, V. \& McKinley, J. (2007b). Performance of clay samples reinforced with vertical granular columns. Can. Geotech. J. 44, No. 1, 89-95.

Charles, J. A. \& Watts, K. A. (1983). Compressibility of soft clay reinforced with stone columns. Proc. 8th Eur. Conf. Soil Mech. Found. Engng, Helsinki, 347-352.

Egan, D., Scott, W. \& McCabe, B. A. (2008). Observed installation effects of vibro-replacement stone columns in soft clay. Proc. 2nd Int. Workshop on the Geotechnics of Soft Soils: Focus on Ground Improvement, Glasgow, 23-29.

$\mathrm{Hu}$, W. (1995). Physical modelling of group behaviour of stone column foundations. PhD thesis, University of Glasgow.

Hughes, J. M. O. \& Withers, N. J. (1974). Reinforcing of soft cohesive soils with stone columns. Ground Engng 7, No. 3, 42-49.

Hughes, J. M. O., Withers, N. J. \& Greenwood, D. A. (1975). A field trial of the reinforcing effect of a stone column in soil. Géotechnique 25, No. 1, 31-44, doi: 10.1680/geot.1975.25.1.31.

McCabe, B. A., Nimmons, G. J. \& Egan, D. (2009). A review of field performance of stone columns in soft soils. Proc. Instn Civ. Engrs Geotech. Engng 162, No. 6, 323-334.

McKelvey, D. (2002). The performance of vibro stone column reinforced foundations in deep soft ground. $\mathrm{PhD}$ thesis, Queen's University of Belfast.

McKelvey, D., Sivakumar, V., Bell, A. \& Graham, J. (2004). Modelling vibrated stone columns in soft clay. Proc. Instn Civ. Engrs Geotech. Engng 157, No. 3, 137-149.

Menzies, B. K. (1976). Discussion: Design manufacture and performance of a lateral strain device. Géotechnique 26, No. 3, 542-544, doi: 10.1680/geot.1976.26.3.542.

Meyerhof, G. G. (1976). Bearing capacity and settlement of pile foundations. J. Geotech. Engng Div. ASCE 102, No. 3, 195228 .

Navaneethan, T. (2003). Pre-yield characteristics and earth pressure coefficient of over consolidated clays. PhD thesis, Queen's University, Belfast.

Priebe, H. J. (1995). The design of vibro replacement. Ground Engng 28, No. 10, 31-37.

Poulos, H. G. (1968). Analysis of the settlement of pile groups. Géotechnique 18, No. 4, 449-471, doi: 10.1680/geot.1968.18. 4.449 .

Poulos, H. G. \& Mattes, N. S. (1974). Settlement of pile groups bearing on stiffer strata. J. Geotech. Engng Div. ASCE 100, No. 2, $185-190$.

Pulko, B. \& Majes, B. (2005). Simple and accurate prediction of settlements of stone column reinforced soil. Proc. 16th Int. Conf. Soil Mech. Geotech. Engng, Osaka 3, 1401-1404.

Raju, V. R. (1997). The behaviour of very soft soils improved by vibro replacement. Proceedings of the ground improvement conference, London, pp. 253-259.

Rowe, P. W. \& Barden, L. (1966). A new consolidation cell. Géotechnique 16, No. 2, 162-170, doi: 10.1680/geot.1966.16. 2.162 .

Slocombe, B. C., Bell, A. L. \& Baez, J. I. (2000). The densification of granular soils using vibro methods. Géotechnique 50, No. 6, 715-725, doi: 10.1680/geot.2000.50.6.715.

Watts, K. S., Johnson, D., Wood, L. A. \& Saadi, A. (2000). An instrumented trial of vibro ground treatment supporting strip foundations in a variable fill. Géotechnique 50, No. 6, 699-708, doi: $10.1680 /$ geot.2000.50.6.699.

Watts, K. S. \& Serridge, C. J. (2000). A trial of vibro bottom-feed stone column treatment in soft clay soil. In Grouting, soil improvement: Geosystems including reinforcement (ed. H. Rathmayer), pp. 549-556. Helsinki: Building Information Ltd.

Wood, D. M., Hu, W. \& Nash, D. F. T. (2000). Group effects in stone column foundations: model tests. Géotechnique 50, No. 6, 689-698, doi: 10.1680/geot.2000.50.6.689. 